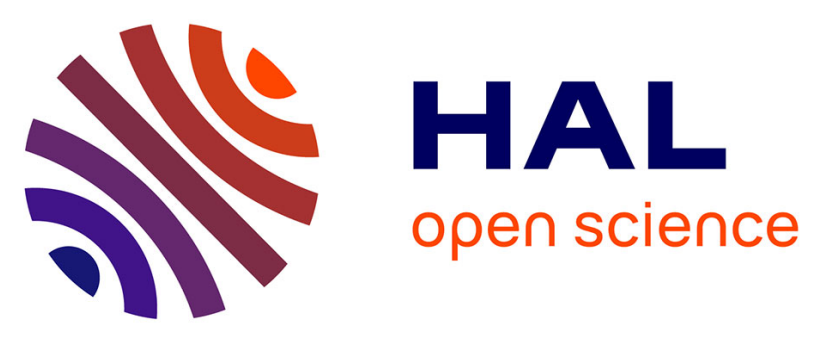

\title{
Electric potential anomaly induced by humid air convection within Piton de La Fournaise volcano, La Réunion Island
}

Raphaël Antoine, Anthony Finizola, Téodolina Lopez, David Baratoux, Michel Rabinowicz, Eric Delcher, Fabrice R. R. Fontaine, Fabrice Jh. Fontaine, Ginette Saracco, Patrick Bachèlery, et al.

\section{To cite this version:}

Raphaël Antoine, Anthony Finizola, Téodolina Lopez, David Baratoux, Michel Rabinowicz, et al.. Electric potential anomaly induced by humid air convection within Piton de La Fournaise volcano, La Réunion Island. Geothermics, 2017, 65, pp.81-98. 10.1016/j.geothermics.2016.01.003 . hal-01376484

\section{HAL Id: hal-01376484 \\ https://hal.univ-reunion.fr/hal-01376484}

Submitted on 2 Nov 2016

HAL is a multi-disciplinary open access archive for the deposit and dissemination of scientific research documents, whether they are published or not. The documents may come from teaching and research institutions in France or abroad, or from public or private research centers.
L'archive ouverte pluridisciplinaire HAL, est destinée au dépôt et à la diffusion de documents scientifiques de niveau recherche, publiés ou non, émanant des établissements d'enseignement et de recherche français ou étrangers, des laboratoires publics ou privés. 


\title{
Electric potential anomaly induced by humid air convection within Piton de La Fournaise volcano, La Réunion Island
}

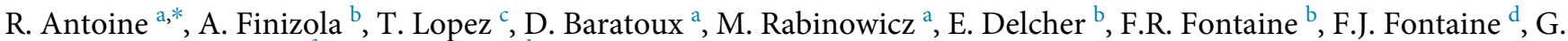 \\ Saracco ${ }^{\mathrm{e}}$, P. Bachèlery ${ }^{\mathrm{f}}$, T. Staudacher ${ }^{\mathrm{d}}$
}

a Centre d'Etudes et d'Expertise sur les Risques, l'Environnement, la Mobilité et l'Aménagement, Laboratoire Régional de Rouen 10, chemin de la Poudrière, CS-90245, 76121 Le Grand Quevilly, France

b Laboratoire Géosciences Réunion, Université de la Réunion, CNRS UMR 7154, Institut de Physique du Globe de Paris, 15, Avenue René Cassin, 97490 Sainte Clotilde, Reunion

c Centre d'Etude Spatiale de la Biosphère, 18, Avenue Edouard Belin, bpi 2801, 31401 Toulouse, France

d Observatoire Volcanologique du Piton de La Fournaise, Institut de Physique du Globe de Paris, Ile de la Réunion, France

e Centre Européen de Recherche et d'Enseignement des Géosciences de l'Environnement, UMR 6635 CNRS, Aix-en-Provence, France

f Observatoire de Physique du Globe de Clermont-Ferrand, France

\section{A B S T R A C T}

Self potential (SP) anomalies over Piton de La Fournaise volcano (La Réunion Island) are generally inter-preted as resulting from meteoritic water porous flow. However, there is no clear evidence that the subsurface is permanently saturated. Recently, a convective subsurface airflow has been evidenced within a quiescent cone at Piton de La Fournaise (Formica Leo). SP and thermal anomalies are reported on the unsaturated edifice and are seen to be correlated. It is proposed that the SP signal is generated by the movement of water films present on the porous matrix, induced by the intense humid airflow within Formica Leo. The structure of the cone, determined from electrical resistivity tomography (ERT), ground penetrating radar (GPR), microgravimetric and kinematic GPS data, is used to constrain a 3D numerical model of the air convection. The calculated temperature is then used to derive the related SP signal, the electrokinetic coupling coefficient being estimated from direct observations of the electrical resistivity of the soil. Extrapolating these results to the scale of the volcano, it is thus proposed that a cold humid air-flow enters the flanks of the $400 \mathrm{~m}$-high terminal dome, flows up along the sloped and stratified volcanic layers before exiting through the vertical fractures around the Dolomieu collapse. It is demonstrated that the SP anomalies catches the main features recovered over the entire volcano. This result strongly sug-gests that humid airflow may play a major role on the generation of SP anomalies at Piton de la Fournaise volcano, and perhaps in other unsaturated volcanic edifices.

\section{Introduction}

SP anomalies have been observed on active volcanoes with an amplitude ranging from a few hundreds millivolts up to several volts (Michel and Zlotnicki, 1998; Finizola et al., 2004; Aizawa, 2008; Barde-Cabusson et al., 2012; Brothelande et al., 2014). Saturated ground water flow is usually considered as the main

\footnotetext{
* Corresponding author. Present address: Centre d'Etudes et d'Expertise sur les Risques, l'Environnement, la Mobilité et l'Aménagement (Cerema), Laboratoire Régional de Rouen, 10, Chemin de la Poudrière, CS-90245, 76121 le Grand Quevilly, France.

E-mail address: raphael.antoine@cerema.fr (R. Antoine).
}

process (so-called electrokinetic phenomenon) inducing the SP signal (Malengreau et al., 1994; Michel, 1998; Aubert et al., 2000; Finizola et al., 2004; Ishido, 2004; Bedrosian et al., 2007). Electrical lows located at the periphery of the volcano are interpreted to be related to saturated meteoric water downflow. Within the active cone, the shallow magma reservoir progressively heats the meteoric water, giving rise to convective hydrothermal upwellings, which induce SP peaks (Zablocki, 1976; Finizola et al., 2002; Hase et al., 2005).

On Piton de La Fournaise volcano (Fig. 1), the fluids are essentially meteoritic. There are a few fumaroles within the Dolomieu caldera and $\mathrm{CO}_{2}$ emanations. In fact, there is no clear evidence that the volcano is permanently saturated with water, despite the occurrence of heavy rains in the area $(\approx 6 \mathrm{~m}$ per year). 

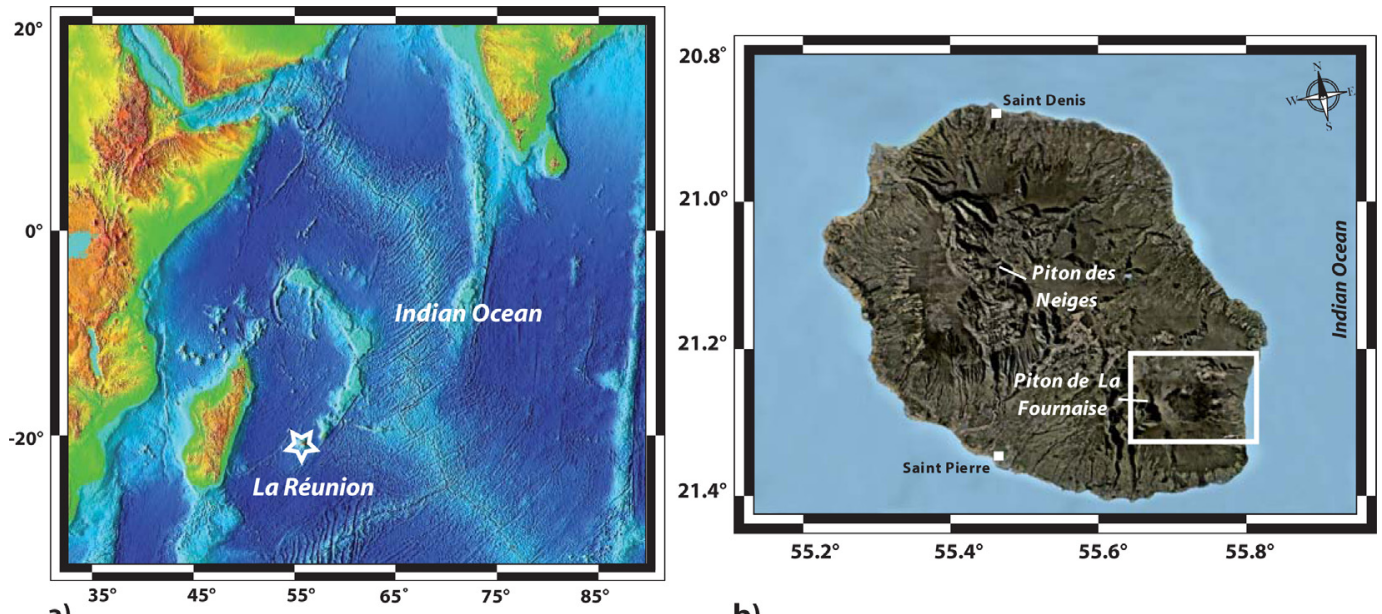

a)

b)
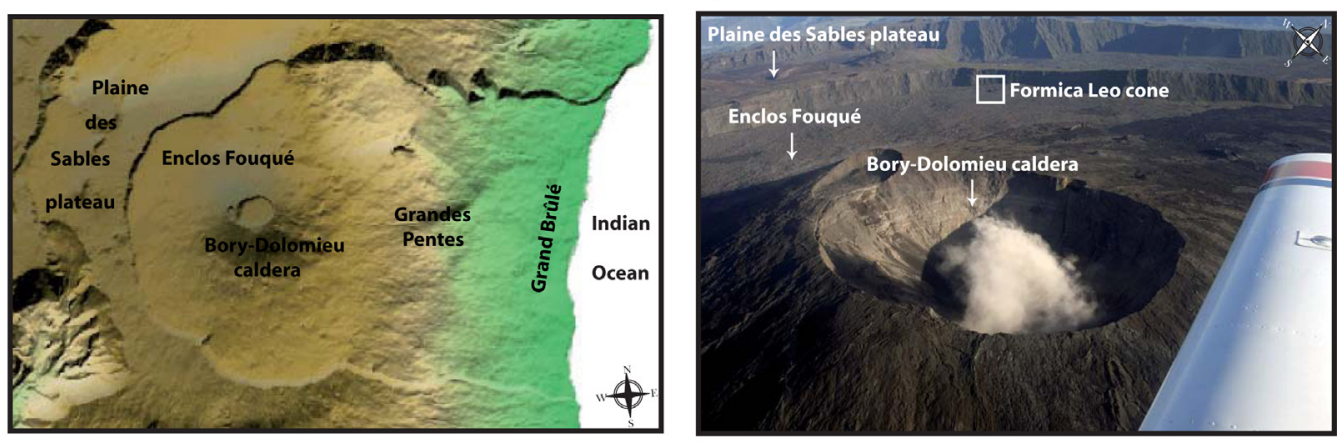

c)

d)

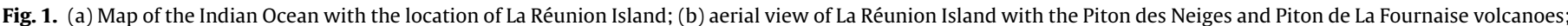

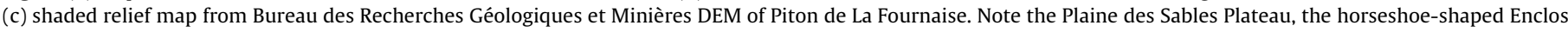
Fouqué and the Bory-Dolomieu caldera; (d) aerial view of Piton de La Fournaise. Note here the location of Formica Leo cone.

Photo by courtesy of Frédéric Caillé.

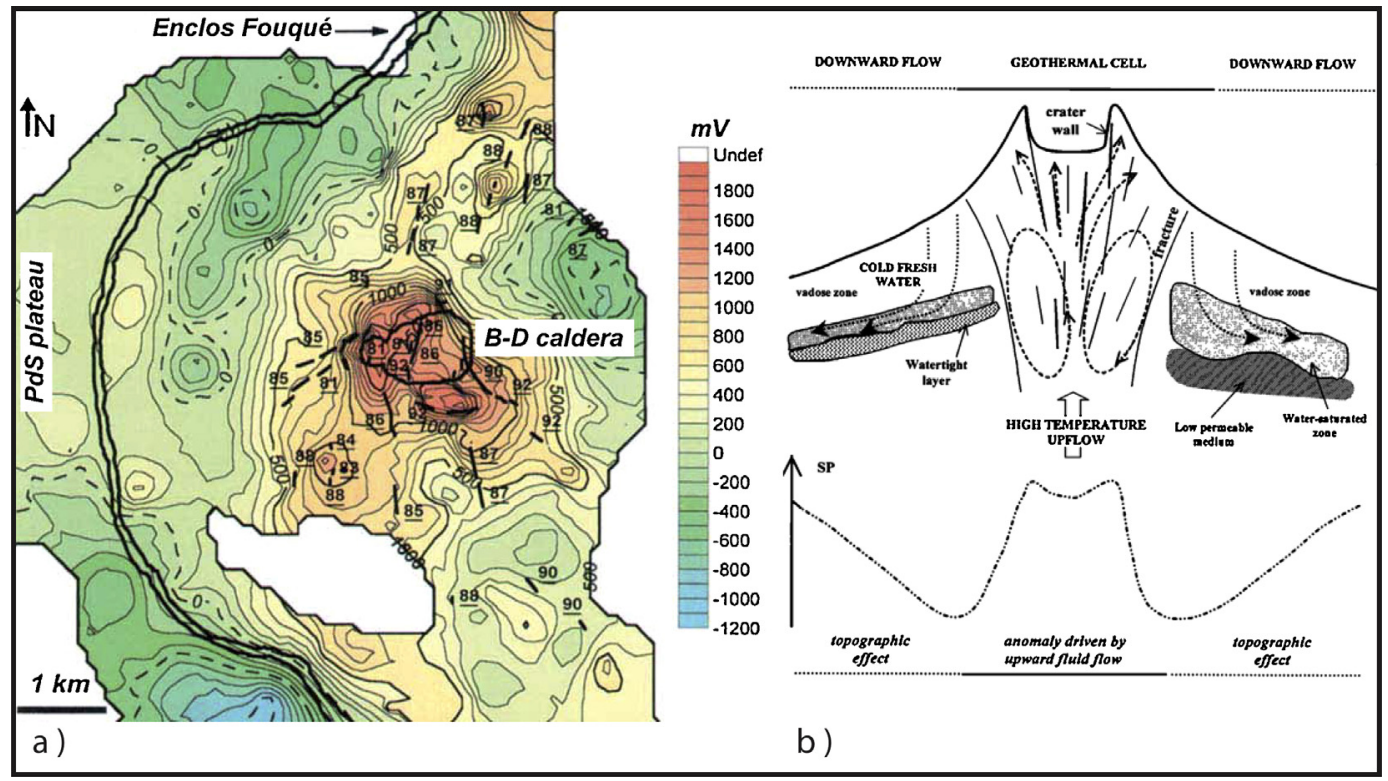

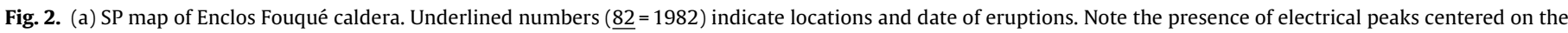

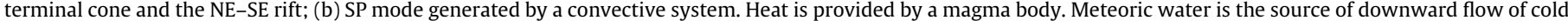
fresh water at the periphery of the volcano ( $P d S$ is used for Plaine des Sables and $B-D$ for Bory-Dolomieu).

Modified from Michel and Zlotnicki (1998). 


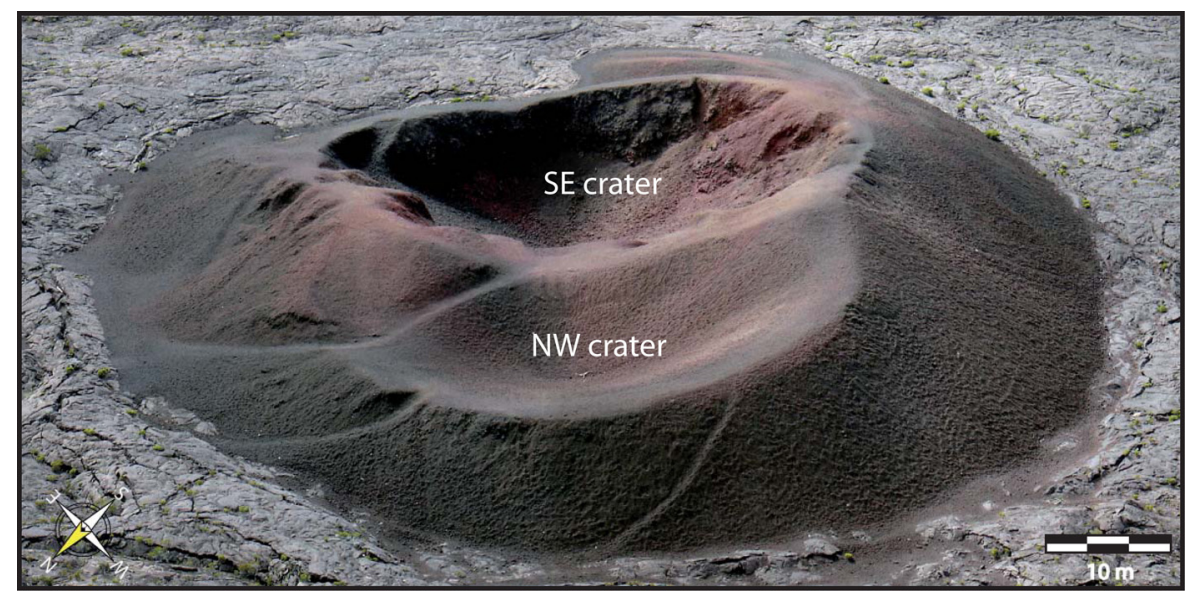

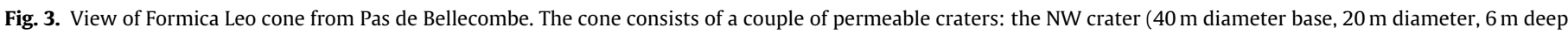
summit crater) and the SE crater $60 \mathrm{~m}$ diameter base, $40 \mathrm{~m}$ diameter, $15 \mathrm{~m}$ deep crater, composed of volcanics bombs and scorias.

However, surprisingly, SP amplitudes as high as $3 \mathrm{~V}$ are observed between the periphery and the terminal cone (Michel and Zlotnicki, 1998; Barde-Cabusson et al., 2012) (Fig. 2). The source of such SP anomalies remains uncertain as it may be located either in the water-saturated zone (Fournier, 1989; Birch, 1993) or in the unsaturated zone (Zablocki, 1978; Jackson and Kauahikaua, 1987; Aubert and Atangana, 1996).

Modeling work on the SP signal at Piton de la Fournaise remains limited. Adler and Thovert (2010) proposed a model of water infiltration within the volcano. The authors solved the Richards equation and calculated the SP signal associated with the infiltration of rain. The model also included the effect of the water saturation on the SP signal, but unfortunately did not describe the convective flow induced by the heat source at depth.

In Antoine et al. (2009), we described a convective subsurface airflow within a $15 \mathrm{~m}$ high quiescent cone over Piton de la Fournaise volcano (Formica Leo, Fig. 3) from thermal infrared, $30 \mathrm{~cm}$-depth temperature measurements and anemometrical data. Recently, an extensive geophysical survey has been realized on the structure(SP, electrical resistivity tomography, microgravimetry, ground penetrating radar, GPS). The SP mapping reveals short wavelengths SP anomalies (100-300 mV) correlated with the thermal signal across the cone. The cause of this high amplitude SP signal observed within the unsaturated soil of Formica Leo is investigated in this paper. More precisely, the main objective of this work is to address whether humid airflow within the cone may be responsible for the observed SP anomaly.

After a brief review of the previous work on the SP within unsaturated porous media (Section 2), we present the geophysical data obtained at Formica Leo. We describe first the SP profiles and their correlations with the thermal infrared observations (Section 3.1). To obtain information on the internal structure of the cone, we collected electrical resistivity, GPR and Microgravimetry data (Section 3.3.2). A 3-D numerical model of the convection is then used to calculate the temperature field in the cone (Section 4.1) and the SP signal induced by the flow. A good quantitative and qualitative agreement is obtained between the observed and calculated SP fields. In particular, it allows specification of the value of the electrokinetic coupling coefficient relating the convective field to the SP field $C$. Finally, using the derived value of $C$, we estimate the SP anomaly that is generated by the humid air convective flow developing within the whole unsaturated layers of the volcano. It is proposed that subsurface humid air convection may explain the SP anomaly observed over the entire volcano (Michel and Zlotnicki, 1998; Barde-Cabusson et al., 2012).

\section{SP in unsaturated porous media}

The SP method allows characterization of fluid flow in porous media. This method is based on the existence of an electric double layer at the liquid-rock interface. A diffuse mobile layer is dragged away from its adsorbed immobile counterparts under the flow of water, creating a charge imbalance (Ishido and Mizutani, 1981). The SP signal $\Delta V(\mathrm{~V})$ generated by the flow of water through the porosity is given by:

$\Delta V=\frac{C \eta \Delta z U}{K}$

where $\eta$ is the dynamic viscosity of the fluid (Pa s), $\Delta z$ is the height of the porous medium ( $\mathrm{m}), K$ is the permeability of the soil $\left(\mathrm{m}^{2}\right)$ and $U$ is the Darcy velocity $\left(\mathrm{m} \mathrm{s}^{-1}\right) . C$ is the electrokinetic coupling coefficient $\left(\mathrm{V} \mathrm{Pa}^{-1}\right)$ :

$C=\frac{\epsilon_{r} \epsilon_{0} \zeta}{\eta_{w} \sigma_{w} s_{w}^{n}}$

where $\epsilon_{r}$ is the relative dielectrical constant of water and is equal to $80, \epsilon_{0}$ is the absolute dielectrical constant $\left(8.85 \times 10^{-12} \mathrm{~F} \mathrm{~m}^{-1}\right)$, $\zeta$ is the electrical potential at the water-rock interface $(\approx 20 \mathrm{mV}$, Darnet and Marquis, 2004), $\eta_{w}$ is the viscosity of the fluid $\left(10^{-3} \mathrm{~Pa} s\right)$ and $n$ is a constant close to 2 (Darnet and Marquis, 2004). $\sigma_{w}$ is the electrical conductivity of the fluid $\left(\mathrm{S} \mathrm{m}^{-1}\right)$ and can be deduced from the Archie's law (Archie, 1942):

$\sigma_{w}=a \frac{\phi^{m}}{\rho_{b}}$

where $\phi$ is the porosity of volcanic soils (0.4), $a$ and $m$ are two constants equal to 1.4 and 3.5, respectively (Keller and Frischknecht, 1996) and $\rho_{b}$ is the bulk resistivity of the soil $\left(\Omega \mathrm{m}^{-1}\right)$. $s_{w}$ is the volume fraction of water in the porosity filled by water and can be derived from a power law (Archie, 1942):

$s_{w}=\sqrt{\frac{\rho_{s}}{\rho_{b}}}$

where $\rho_{s}$ is the bulk resistivity of the water saturated soil.

Up to now, few field observations have been reported on SP over unsaturated areas on volcanoes. Zodhy et al. (1973) reported an anomaly of several volts over the $\mathrm{H}_{2} \mathrm{O}$ vapor geothermal zone of Mud Volcano, Yellowstone Park. Aubert et al. (1984) observed a $200 \mathrm{mV}$ SP anomaly in a fumarole area at Mount Etna. They show that the SP anomaly are produced in fissures discharging high amount of $\mathrm{He}, \mathrm{Rn}$, and $\mathrm{CO}_{2}$ gases. 
Several laboratory experiments were performed to characterize the SP signal in unsaturated porous media. Revil et al. (1999) stated that the electric field is enhanced for a water saturation greater than the residual level. Marsden and Tyran (1986) pointed out that the flow of steam induces electrical potentials in capillary tubes. The signal is seen to be nonlinearly coupled with flow rate and water content in the steam up to $100 \mathrm{mV}$. The SP generation is explained by the presence of thin condensation films at the surface of the tube interspaced by electrically resistive $\mathrm{H}_{2} \mathrm{O}$ vapor. The same experience was realized with superheated steam (water vapor heated at a temperature higher than the boiling point and not condensing). Such flow did not induce any electrical potentials. Antraygues and Aubert (1993) measured the electrical potentials generated by the flow of $\mathrm{H}_{2} \mathrm{O}$ vapor along a vertical column of sands. A positive electrical gradient was measured above convective upwellings. The SP was thought to be induced by the relative motion between the solid phase (porous material) and the water droplets in suspension in the gaseous phase is then invoked. Vieira et al. (2012) shown in his experiments that the amplitude of the electrical potentials increases above an injection of gas $\left(\mathrm{CO}_{2}\right)$ within a sandbox. Although the amount of gas could not be quantified from signals, injection timespan and increasing of injection rate were identified by the SP method.

Some authors experimentally estimated the coupling coefficient $C$ in unsaturated conditions. $C$ has been shown to be drastically amplified when air and water are present in the soil. Morgan et al. (1989) injected air bubbles in a granite sample previously saturated with water and observe an increase of a half order of magnitude of C. Also, Sprunt Eve et al. (1994) shown that it is possible to increase $C$ by more than two orders of magnitude during the injection of air bubbles into a limestone. Moore and Glaser (2004) observed the same effect due to 2-phase water/steam flow in an geothermal laboratory experiment. On the contrary, some authors suggested that $C$ remains constant or decreases when the water saturation decreases (Guichet et al., 2003; Strahser et al., 2011; Revil and Cerepi, 2004). Allègre et al. (2014) suggested that $C$ increases and then decreases during progressive water desaturation. In fact, laboratory experiments on SP in unsaturated media are difficult to realize because (i) experiments may not be easily reproducible due to the complex behavior of gas in porous media; (ii) the SP amplitude may vary with the size of the electrode used for the measurements (Vieira et al., 2012), (iii) signal instabilities due to bad contacts can be generated at the electrode scale; (iv) the low amplitude of the SP renders the signal difficult to measure. Water condensation/evaporation at the rock/fluid interface may also influence the measurements. Finally, in the case of numerical simulation, Darnet and Marquis (2004) calculated the electrokinetic coupling coefficient for an unsaturated sand. They show that $C$ increases by more than one order of magnitude relatively to a saturated sandy soil when it is saturated with $20 \%$ water and $80 \%$ air $\left(4 \times 10^{-5} \mathrm{~V} \mathrm{~Pa}^{-1}\right.$ instead of $\left.2.5 \times 10^{-6} \mathrm{~V} \mathrm{~Pa}^{-1}\right)$. From the articles that are cited above, we argue that (1) the influence of water saturation on $C$ is still in debate; (2) the role of gas flow within porous media on the SP is not established.

\section{Correlation between the SP and thermal signals at Formica Leo}

\subsection{SP measurements}

Four electrical profiles were realized across the NW and SE craters (P1 and P2) and following their rims (P3 and P4) (Fig. 4a). The SP equipment consisted of a high-impedance voltmeter, a pair of Petiau $\mathrm{Pb}-\mathrm{PbCl}_{2}$ non-polarizing electrodes and a $300 \mathrm{~m}$ long insulated $\mathrm{Cu}$ cable. A reference electrode was placed on the pahoehoe surrounding the cone (SP ref in Fig. 4a). During field work, soil-electrode contacts were tested before each measurement. Experimental errors were minimized by averaging five repeated measurements at each location. Fig. 5 presents the four profiles with a resolution of $1 \mathrm{~m}$. P1 profile crosses both craters of Formica Leo in the NW-SE direction (Fig. 5a). Three peaks with an amplitude of 50,200 and $220 \mathrm{mV}$ are found at the rims of the cone (r1, r2 and r3 locations, Fig. 4a). The maximum of the SP signal (r4, $270 \mathrm{mV})$ corresponds to a possible remnant of an outer rim located on the outer flanks of the SE crater (Fig. 4a and b). Two minima are observed at the bottoms b1 and b2 of the NW and SE craters, respectively. The amplitudes of the peaks at the SE crater are greater than those at the NW one. P2 profile crosses the NW crater in NE-SW direction

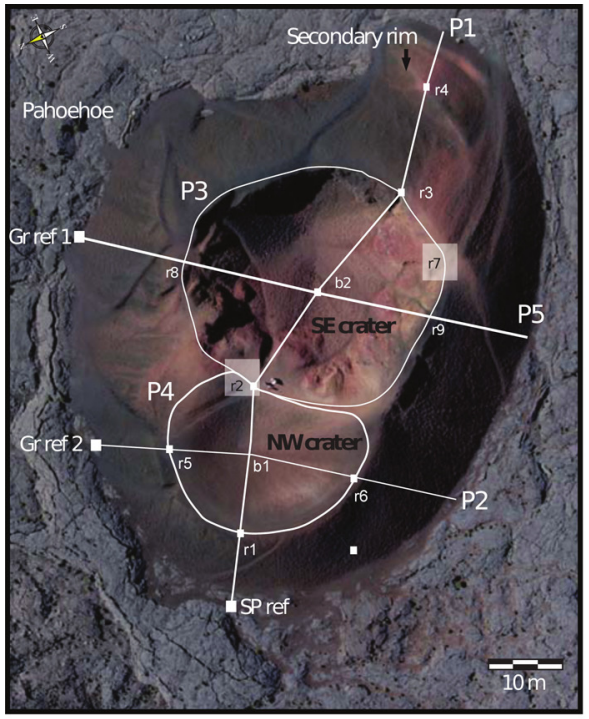

a)

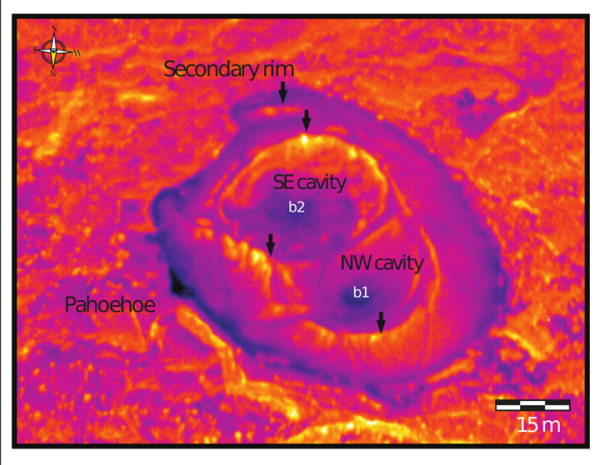

b)

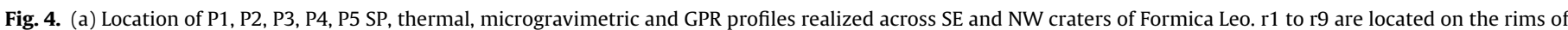

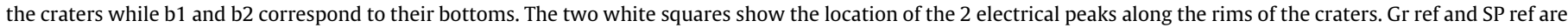

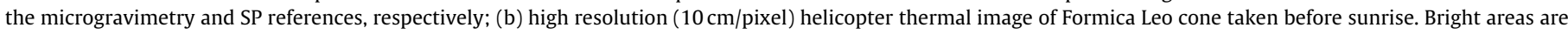
hot, while dark ones are cold. Note the presence of cold areas in the bottom of both craters (b1 and b2) and annular hot areas at their rims (pointed out by black arrows). 


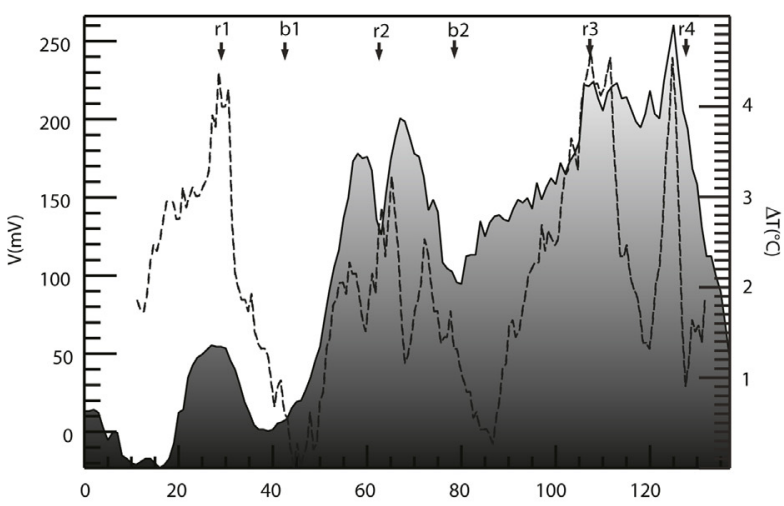

a)
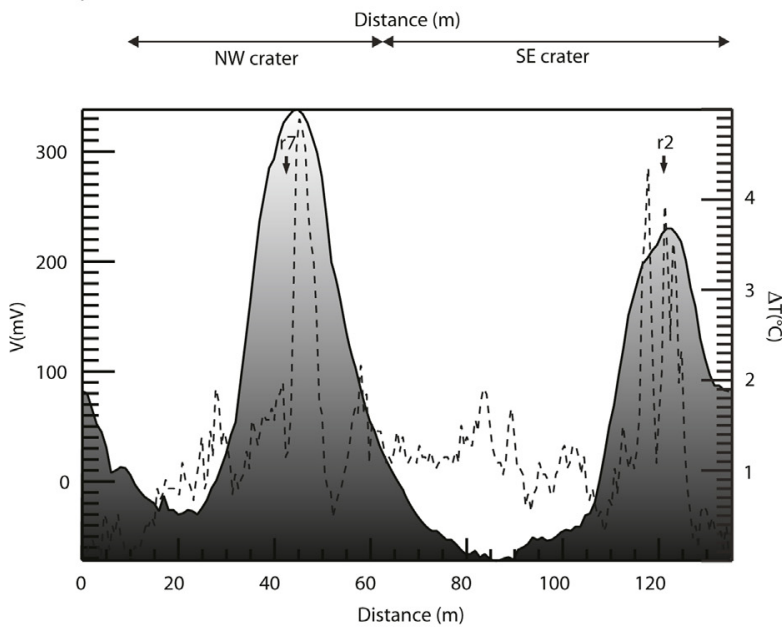

c)
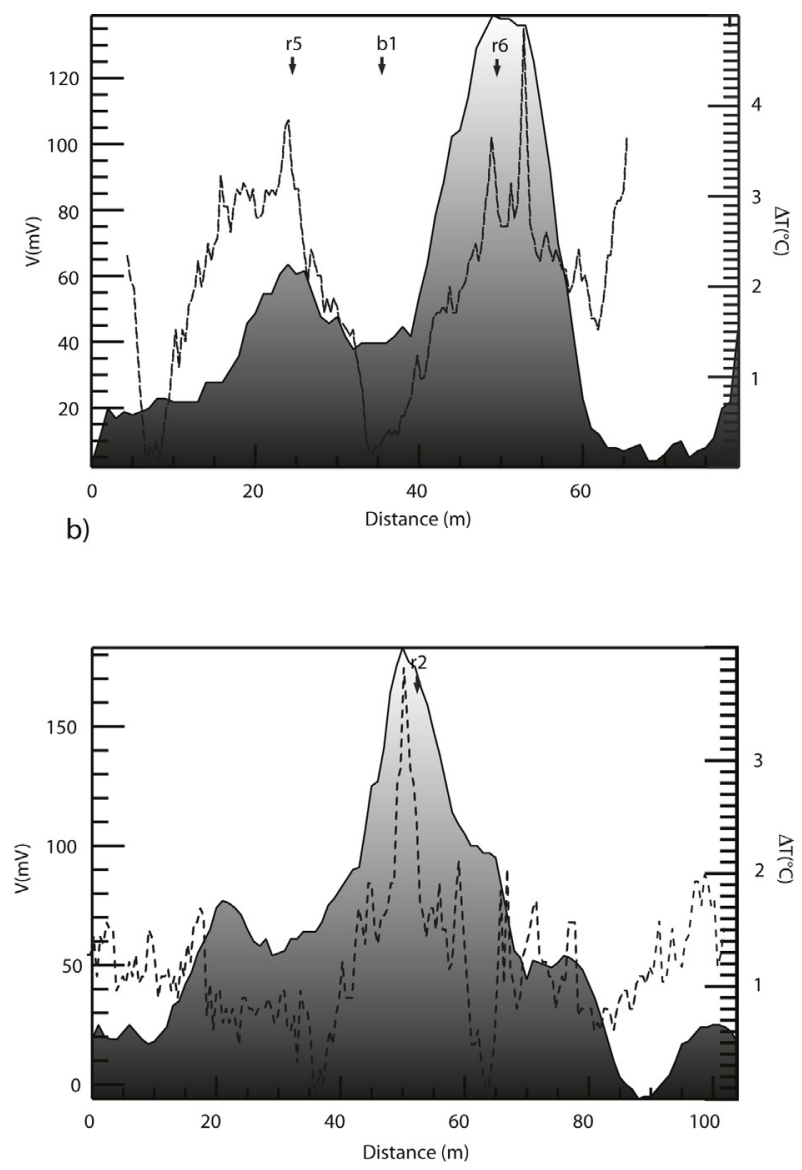

d)

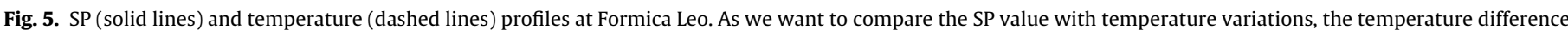

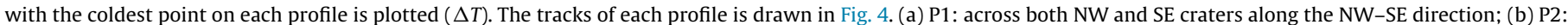

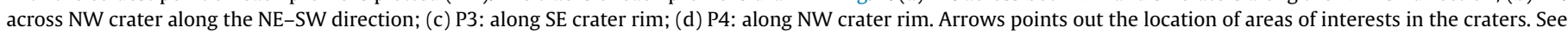
Fig. 4 for profile tracks.

(Fig. 5b). Two peaks of 60 and $130 \mathrm{mV}$ are found at $\mathrm{r} 5$ and $\mathrm{r} 6$, respectively (Fig. 4a and b). P3 profile follows the SE crater rims (Fig. 5c): two peaks with amplitudes of 230 and $330 \mathrm{mV}$ are found over the $\mathrm{r} 2$ and r7 locations, respectively (white transparent square, Fig. 4a). A similar situation is found along the NW crater rim (P4 profile), and a unique $180 \mathrm{mV}$ peak is detected along the $\mathrm{r} 2$ location (Fig. 5d).

\subsection{Thermal measurements}

A high resolution aerial thermal image of Formica Leo was taken one year after the SP data acquisition (Fig. 4b). To avoid solar radiation, the image was acquired just before sunrise during a helicopter flyby. We used a (C) FLIR Thermacam PM695 owned by Observatoire Volcanologique du Piton de La Fournaise. The PM 695 camera measures thermal radiations in the 7.5-13 $\mu \mathrm{m}$ domain and has a thermal sensitivity of $0.08^{\circ} \mathrm{C}$. Given the elevation of the helicopter above Formica Leo, the resolution of the image is approximately $10 \mathrm{~cm} /$ pixel. From these data, temperature data have been extracted along P1, P2, P3 and P4 profile using an emissivity of 1 (brightness temperature). Emissivity of basalt is generally close to 0.9 , but as no measurement of the exact emissivity of this soil is available, we chose to develop our argument based on brightness temperature differences, rather than based on the kinetic temperature. Then, brightness temperature differences above the minimum of each profile are represented in Fig. 5. The rims of the cone ( $r 1, r 2$, $r 3, r 5, r 6$ and $r 7$ ) are systematically hot, while the bottoms of the craters are cold. The rim to bottom temperature contrast is $5^{\circ} \mathrm{C}$.
Fig. $5 \mathrm{c}$ displays the thermal measurement along the SE crater rims (P3 profile). We note the presence of two peaks at $\mathrm{r} 2$ and $\mathrm{r} 7$ locations (Fig. 4a and b). The amplitudes of the peaks are close to $4{ }^{\circ} \mathrm{C}$. Finally, a unique peak is observed along the NW crater rim (Fig. 5d) at $\mathrm{r} 2$ point. These observations show that the thermal field is clearly correlated with the electrical field. Moreover, the discovery of thermal peaks suggests the existence of an important variability of the temperature on the rims and the existence of a complex thermal field over the whole volcanic cone.

\subsection{Structure of the cone}

The air convection depends on the subsurface structure of the cone, in particular on its permeability and on the organization of the different permeable and impermeable layers. Such a structure can be deciphered with electrical resistivity tomography (ERT), GPR and microgravimetric surveys.

\subsubsection{Electrical resistivity tomography}

We carried out a two dimensional electrical resistivity survey along the P5 line crossing the SE crater. Electrical resistivity measurements were obtained using a set of 64 stainless steel electrodes, 2 cables of 32 take-out with a spacing of $2 \mathrm{~m}$ and the ABEM Terrameter SAS-4000 resistivimeter. The contact of the electrodes with the ground was improved by adding salty water. The contact resistance of the electrodes with the ground was about $2 \mathrm{k} \Omega$, driving an injection current between 5 and $20 \mathrm{~mA}$ into the ground. The total length 


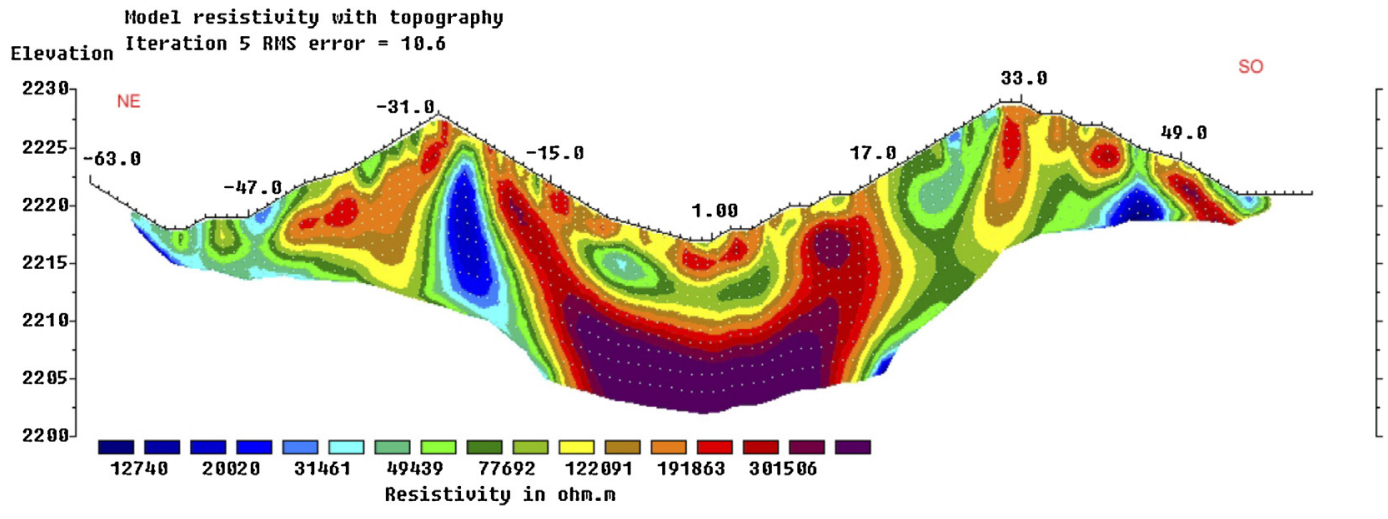

Fig. 6. Electrical resistivity cross-section of the SE crater along P5 profile (see Fig. 4a) obtained by electrical resistivity tomography.

of the cable is $126 \mathrm{~m}$ (64 electrodes regularly spaced every $2 \mathrm{~m}$ ). Acquisitions were performed with the Wenner array because of its good signal-to-noise ratio. This configuration allows reaching a penetration depth of about $20 \mathrm{~m}$. Topography was obtained from a Digital Elevation Model $(5 \mathrm{~m} \times 5 \mathrm{~m})$ and the $X$ and $Y$ coordinates were determined in the field using a Garmin GPS receiver. Topography information was included in the apparent resistivity data files. The data were inverted by means of the commercial package Res2dInv (Loke and Barker, 1996) using a finite element grid for the forward modeling of the voltage response to current injection. The RMS error was $10.4 \%$ at iteration 5 . The effect of the topography is included in the model. Fig. 6 displays the resistivity across the SE crater. Domains of high resistivities $\left(\approx 3 \times 10^{5} \Omega \mathrm{m}\right)$ represent zones of high porosity. The central part of the cavity is filled with a material with a resistivity greater than $10^{5} \Omega \mathrm{m}$ whereas the flanks have a resistivity as low as $1.2 \times 10^{4} \Omega \mathrm{m}$. This supports the idea that the flanks act as barriers for the fluid flow. The resistivity of a water saturated basaltic soil is about $10^{3} \Omega \mathrm{m}$ (Lénat et al., 2000). Thus, given the high resistivities of the soil of Formica Leo, only a partial filling of the porosity with water is conceivable. Assuming that the bulk resistivity of the tomography model $\rho_{b} \approx 10^{5} \Omega \mathrm{m}$, we deduce from Eq. (4) that $s_{w} \approx 10 \%$. It means that in the $40 \%$ porosity of the aggregates filling the cone, only $10 \%$ is filled with water, which likely forms films coating the rock surface. At Piton de la Fournaise, atmospheric air is characterized by a mean annual relative humidity of $85 \%$. It frequently goes past to the dew-point, leading to the condensation of water in the atmosphere and the soil. We drilled a $1 \mathrm{~m}$-depth hole in the bottom of the crater and observed liquid films systematically coating the surface of the rocks and thus providing electrical continuity to the porous medium. Consequently, the $4 \%$ bulk volume of water derived from Eq. (4) appears reasonable. Finally, using the Archie's law (Eq. (3)), we find a value of $9 \times 10^{-6} \mathrm{~S} \mathrm{~m}^{-1}$ for the electrical conductivity of the fluid flowing within the porous medium $\sigma_{w}$. The determination of $\sigma_{w}$ and $s_{w}$ (Eqs. (3) and (4)) leads to the determination of the electrokinetic coupling coefficient $C=0.145 \mathrm{~V} \mathrm{~Pa}^{-1}$ (see Eq. (2)), i.e. 6 orders of magnitude greater than for the saturated case. Note that at Formica Leo, the coupling coefficient $C$ seems to depend on the electrical resistivity of the medium at the first order. Indeed, another ERT survey has been led in 2011 with 64 electrodes spaced every $5 \mathrm{~m}$. Resistivities as high as $680,000 \Omega \mathrm{m}$ have been calculated, i.e. two times higher than the one observed in 2008. In this case, the amplitude of the SP signal was $700 \mathrm{mV}$ at that time, i.e. two times higher than the one observed in 2008.

\subsubsection{Ground penetrating radar}

(C) RAMAC GPR measuring equipment with $100 \mathrm{MHz}$ unshielded antennas was used for the acquisition. Data were collected along the P2 and P5 profiles crossing the NW and SE crater, respectively
(Fig. 4a). The GPR console was connected to the transmitter and the receiver by fiber-optic cables. The console and the power supply were carried in a backpack by the operator, who triggered the measurements with a RAMAC monitor. The radar was used in reflection mode, and the antennas were moved perpendicular to the profile with a constant separation of $1 \mathrm{~m}$. The influence of the operator and his electronic equipment on the transmitted signal was minimized imposing a distance of $3 \mathrm{~m}$ between the antenna and the operator.

The data were processed using the REFLEXW ${ }^{\mathrm{TM}}$ software (Sandmeier, 2004). Dewow was first applied to filter the low frequency noise associated to the air and direct waves that travel along the air/ground interface (Sandmeier, 2004). Static correction was then realized to compensate the time delay of the first arrival. Background removal filtering allowed to get rid of the noise due to the reflections of the waves within the antenna, as well as at the antenna/ground interface. A band pass filter between 20 and $400 \mathrm{MHz}$ was then applied to remove the noise at the high and low end of the amplitude spectrum. Finally, the amplitude of the signal at depth was enhanced by an automatic gain control (AGC) processing. Considering an average velocity of $0.12 \mathrm{mns}^{-1}$ for an unconsolidated basaltic soil (Heggy et al., 2006), arrival times were converted to depth below the topography with no slope effect correction. The GPR was able to penetrate into the subsurface of the cone down to $7 \mathrm{~m}$ with a resolution of $30 \mathrm{~cm}$.

Fig. 7a displays the radargram obtained across NW crater. A succession of subparallel interfaces is observed. The different reflectors follow the topography of the crater and steeper layers are even detected (for example, within the inner flanks, between 90 and $110 \mathrm{~ns}$ ). This layering reflects the eruptive events which built both craters. These observations are in agreement with those over other volcanic cones (Head and Wilson, 1989; Wohletz and Heiken, 1992). Unconformities between the steep slopes within the inner flank and subparallel reflectors are visible between 110 and $130 \mathrm{~ns}$. They may represent the interface between the cone and the underlying basaltic bedrock located at about $7 \mathrm{~m}$ depth (see Fig. 7a). Fig. 7b displays the radargram obtained through the SE crater. A succession of sub-parallel reflectors also following the topography are observed. No unconformities have been detected at depth, suggesting that the interface between the cone and the bedrock is not reached by the waves. The velocity of the electromagnetic wave depends on the dielectrical permittivity of the soil, which depends on the fluid saturating the porous media. The detection of several well-defined reflectors up to several meters depth definitively proves that the soil is not saturated with water.

\subsubsection{Microgravimetry}

Two microgravimetry profiles have been realized along P2 and P5 profiles (Fig. 4). The gravity measurements were made with 

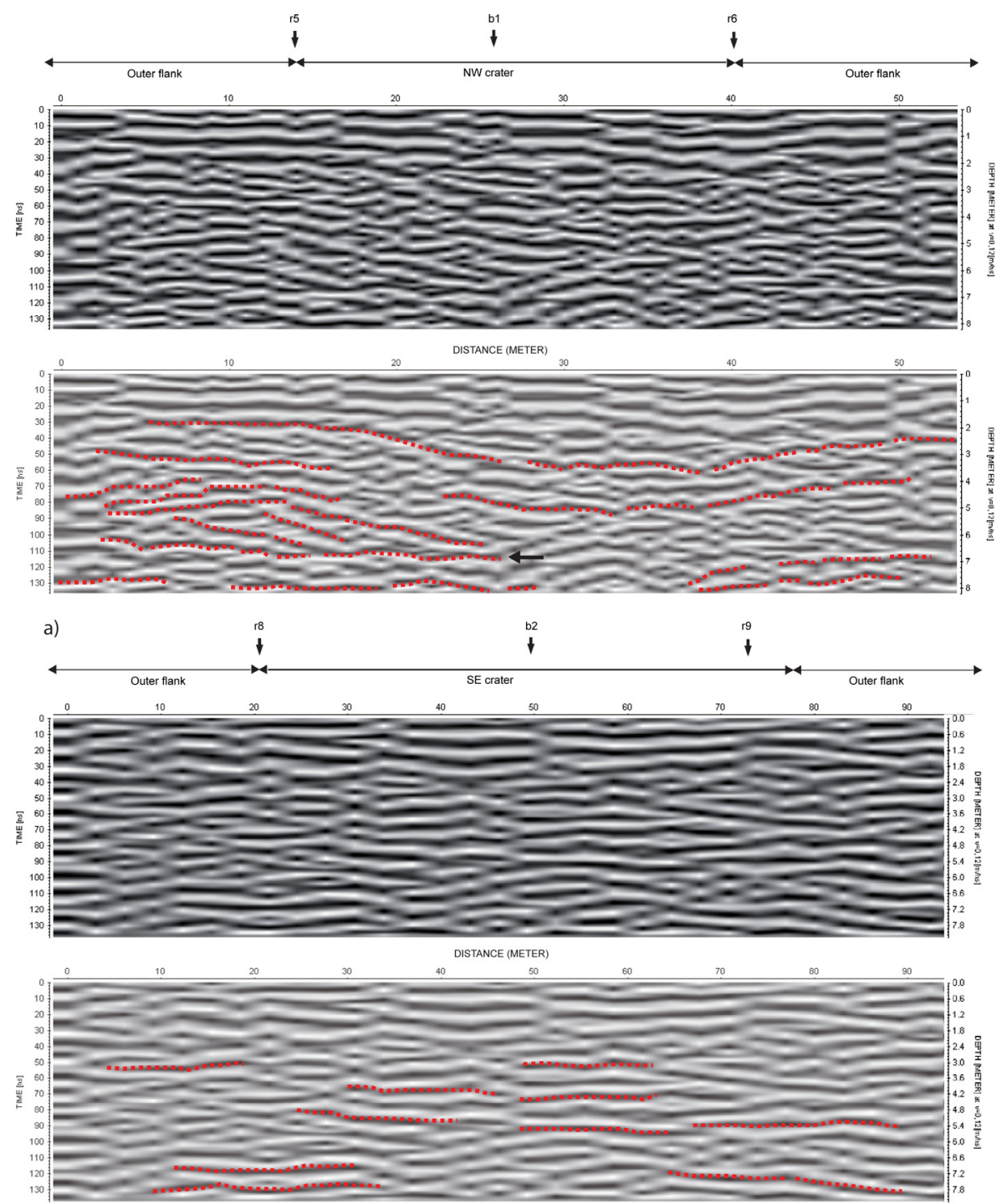

b)

Fig. 7. Radargrams of the subsurface of NW and SE craters along P2 and P5 profiles (see Fig. 4a). The red dashed lines underline the stratigraphy of the craters. The arrow highlights the presence of an unconformity at $110 \mathrm{~ns}$ in the NW crater. (For interpretation of the references to color in this figure legend, the reader is referred to the web version of this article.)

a 2-m interval. A Scintrex CG3-M microgravity meter owned by Bureau Gravimétrique International, Toulouse (gravity resolution of 1 microgal $=10^{-8} \mathrm{~m} \mathrm{~s}^{-2}$ ) was used. Each gravity profile has a different reference ( $\mathrm{Gr}$ ref 1 and Gr ref 2, Fig. 4a) taken outside Formica Leo. Differential GPS measurements (using an Ashtech Z-surveyor dual-frequency GPS receiver) were performed to get the absolute position within a few centimeters accuracy. To get it, stop and go measurements (with $180 \mathrm{~s}$ acquisition time) were realized close to the reference station (less than $1 \mathrm{~km}$ away). Although the CG3-M gravity meter provides real time data processing including Earth tide or instrumental drift corrections, these corrections are not accurate enough for microgravity studies (Bonvalot et al., 1998; Jousset et al., 2000; Gabalda et al., 2003). Thus, the gravity corrections were computed up to the microgal level using the CG3TOOL package designed for the processing of CG3-M (Gabalda et al., 2003). The first data reduction includes Earth tide corrections, latitude corrections, atmospheric corrections and height corrections resulting in errors lower than $0.03 \mathrm{mgal}$. To correct gravity from elevation, we calculate the Bouguer anomaly $G_{b}$ verifying:

$G_{b}=G_{m}+\frac{2 G h}{R_{e}}-2 \pi \rho_{b} G h$

where $G_{m}$ is the measured gravity (gal), $G$ is the gravitationnal constant $\left(6.67 \times 10^{-11} \mathrm{~m} \mathrm{~s}^{-2}\right), R_{e}$ is the Earth radius $(\approx 6368 \mathrm{~km}), \rho_{b}$ designates the density of the soil $\left(\approx 2000 \mathrm{~kg} \mathrm{~m}^{-3}\right)$ and $\mathrm{h}$ is the height given by GPS (m) (Fig. 5).

Figs. $8 \mathrm{~g}$ and h display $G_{b}$ along P2 and P5 profiles. Two unique peaks of 0.39 and $0.92 \mathrm{mgal}$ are found at the center of NW and SE craters, respectively (Fig. 4a). This excess of mass may result from a shallow dense basaltic intrusion which was emplaced and outgassed within the feeding conduit of both craters. Such events have already been documented in similar cones (Awdankiewicz, 2004). To have a rough estimation of the depth of the basaltic intrusion, the 

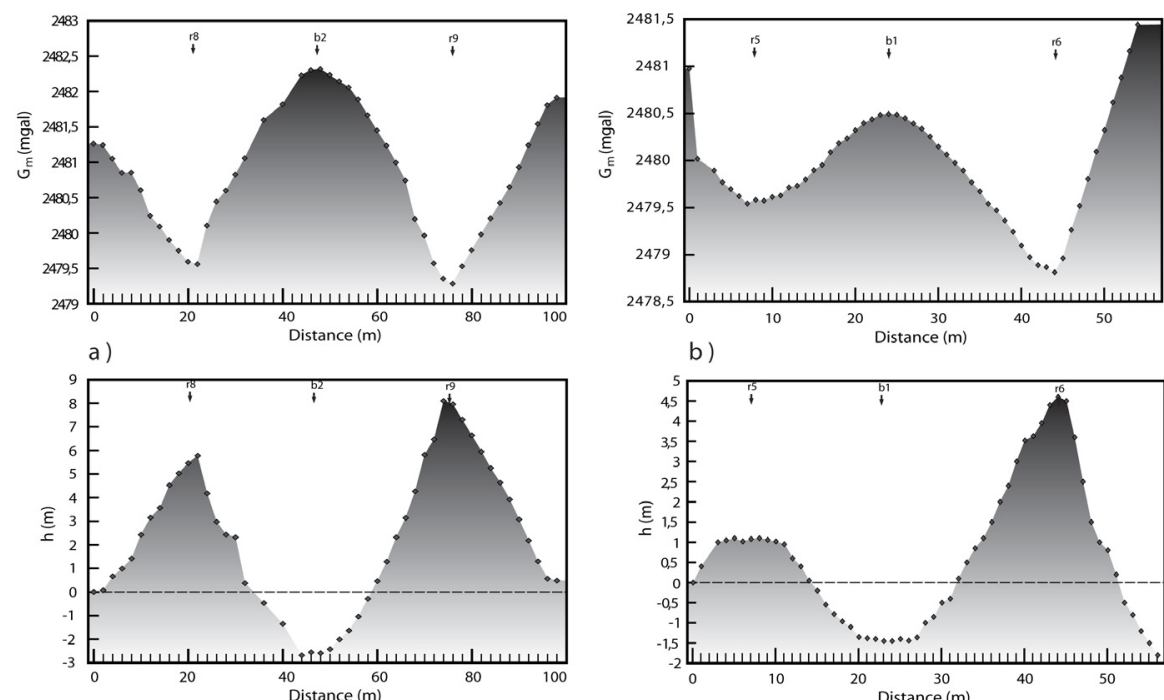

b)

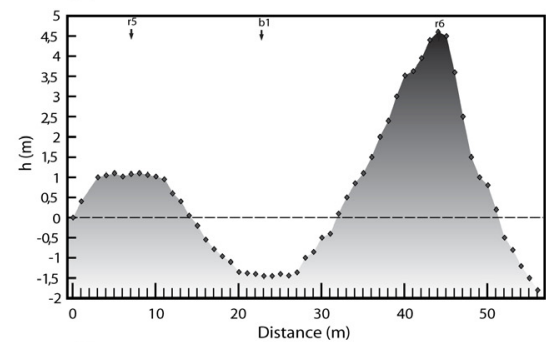

C)

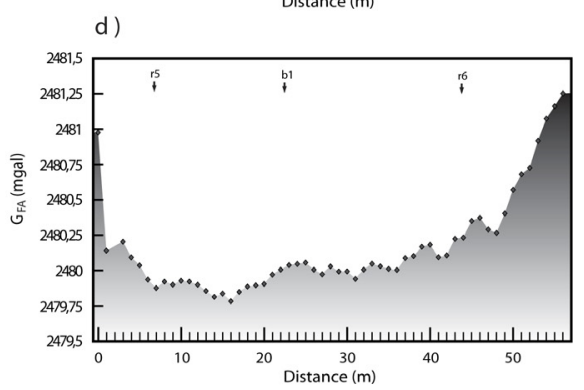

e)
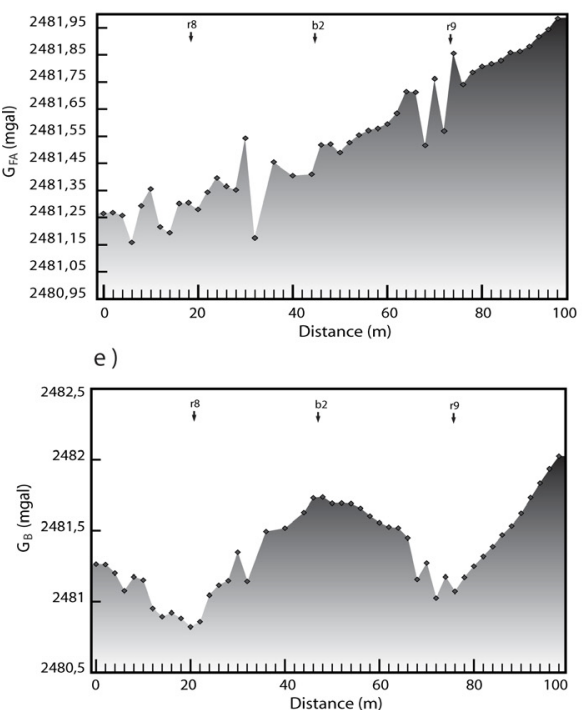

g)

SE crater

f)

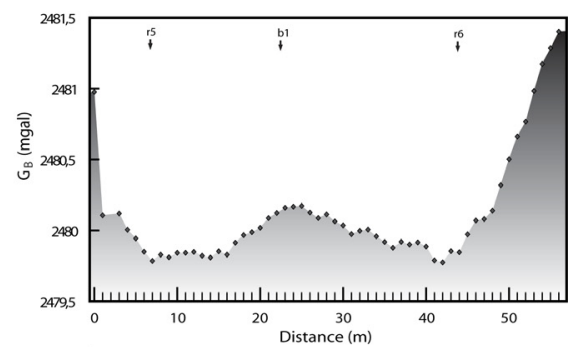

h )

NW crater

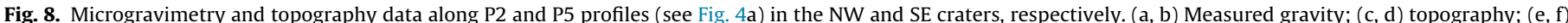

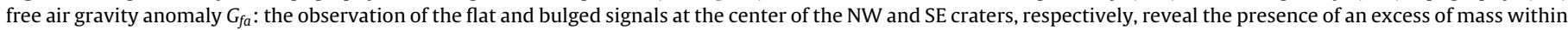
the cone; $(\mathrm{g}, \mathrm{h})$ Simple Bouguer gravity anomaly $G_{b}$.

observed gravity peaks were compared to the analytical solution of the gravity anomaly generated by an infinite vertical cylinder:

$G_{c}=2 \pi G \Delta \rho\left\{\left(z^{2}+R^{2}\right)^{1 / 2}-z\right\}$

where $\Delta \rho$ is the density contrast between the dense cylinder and the soil, $z$ is the depth of the top of the cylinder $(\mathrm{m})$ and $R$ its radius (m) (Telford et al., 1990). The solution of this inverse problem is not unique, but if we consider reasonable values of density contrast and depth of the cylinder, the anomaly peak can be used to find a range of plausible values for the cylinder radius (i.e. the dimension of the feeding conduit). Considering a gravity contrast $\Delta \rho$ of $900 \mathrm{~kg} \mathrm{~m}^{-3}$, $z=7 \mathrm{~m}$ and $z=14 \mathrm{~m}$ for the NW and the SE crater, respectively, cylinder radius of $15 \mathrm{~m}$ and $35 \mathrm{~m}$ are obtained to account for the 0.39 and 0.92 mgal anomaly recorded over the craters. These values are consistent with the sizes of the craters of the Formica Leo cone.

\subsubsection{Summary of the cone structure and implications for heat and mass transfer}

The structure of Formica Leo cone has been inferred from the combined interpretation of ERT, GPR and Microgravimetry. The edifice is composed of a sequence of sloped resistive layers of different thickness with the possibility of interbedded scorias. A dense material is present below the NW and SE craters and is associated with the feeding conduit of Formica Leo (Fig. 9). Such dense intrusion typically has a permeability 13 orders lower than that of the scoria (Fontaine et al., 2002) and thus constitutes an impermeable substratum for the subsurface airflow.

\section{Numerical modeling of the air convection and the SP within Formica Leo}

In Section 3.1, we evidenced a correlation between a complex thermal field, with localized thermal peaks along the rims of the craters and the SP signal. The discovery of these thermal peaks suggests the existence of a tridimensional convective flow along 


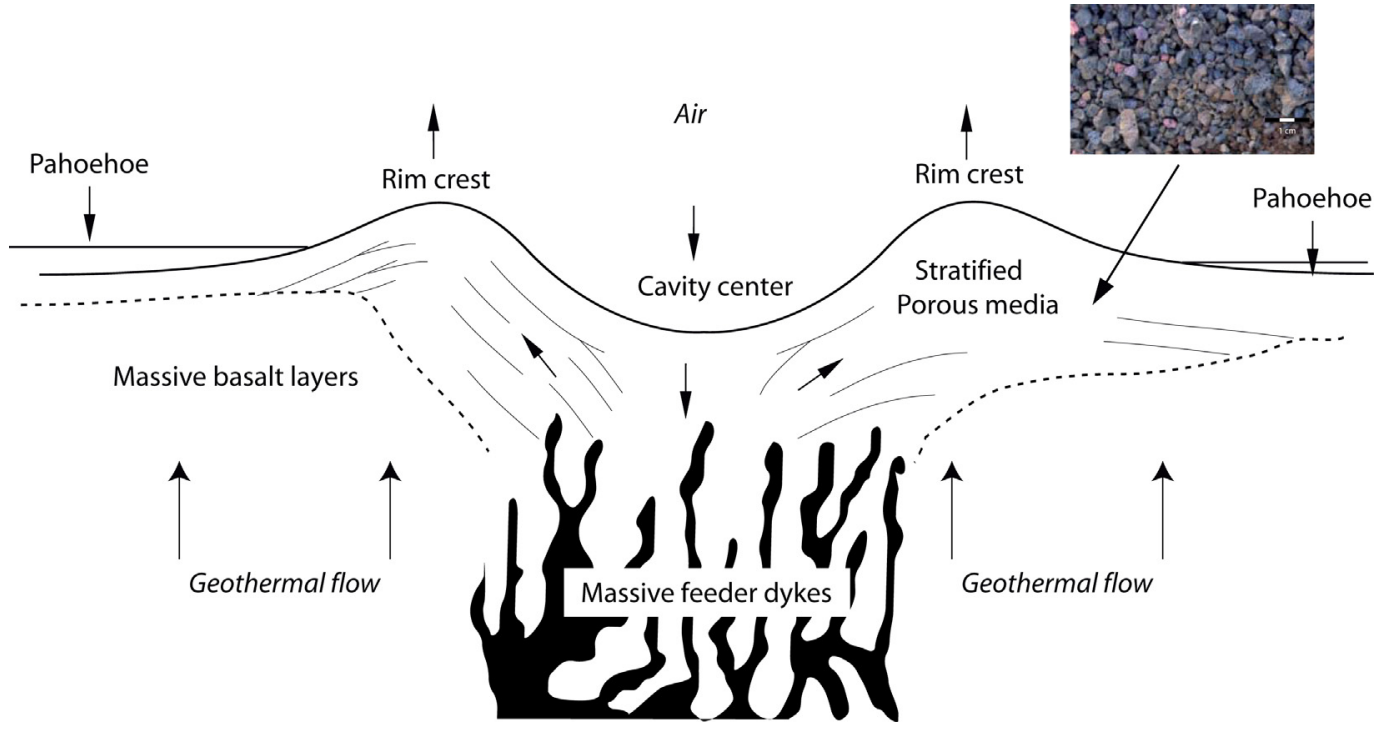

Fig. 9. Sketch of the internal structure of Formice Leo cone inferred by GPR and micro-gravimetry.

the structure. In this section, the geological model obtained in Section 3.3 is used to constrain a 3D numerical code of air convection within Formica Leo. Then, the observed SP signal is calculated from the modeled temperature field.

\subsection{Equations of the convection}

In the present situation, the flow is slow enough to assume thermal equilibrium between the air in the pores and the porous matrix (Antoine et al., 2009). Accordingly, it can be derived from the following equation:

$(\rho c)_{b} \frac{\partial T}{\partial t}+(\rho c)_{a} U \cdot \operatorname{grad} T=k\left(\frac{\partial T^{2}}{\partial x^{2}}+\frac{\partial T^{2}}{\partial y^{2}}+\frac{\partial T^{2}}{\partial z^{2}}\right)$

where $T$ is the temperature $(\mathrm{K}), x, y, z$ are the three Cartesian coordinates, $z$ is positive downward, $\rho_{b} c_{b}$ and $\rho_{a} c_{a}$ are the volumetric heat capacities of the rock and the air $\left(\mathrm{J} \mathrm{m}^{-3} \mathrm{~K}^{-1}\right)$, respectively, $U$ is the Darcy velocity $\left(\mathrm{m} \mathrm{s}^{-1}\right)$ and $k$ is the thermal conductivity of the soil $\left(\mathrm{W} \mathrm{m}^{-1} \mathrm{~K}^{-1}\right)$.

Dividing Eq. (7) by $(\rho c)_{b}$ yields to:

$\frac{\partial T}{\partial t}+\gamma U \cdot \operatorname{grad} T=\kappa\left(\frac{\partial T^{2}}{\partial x^{2}}+\frac{\partial T^{2}}{\partial y^{2}}+\frac{\partial T^{2}}{\partial z^{2}}\right)$

where $\gamma$ is the heat capacity ratio:

$\gamma=\frac{\rho_{a} c_{a}}{\rho_{b} c_{b}}$

and $\kappa$ is the thermal diffusivity of the media $\mathrm{m}^{2} \mathrm{~s}^{-1}$ :

$\kappa=\frac{k}{\rho_{b} c_{b}}$

The governing equations for fluid flow follow from Darcy's law:

$-\frac{\mu}{K} u=\frac{\partial p}{\partial x}$

$-\frac{\mu}{K} v=\frac{\partial p}{\partial y}$

$-\frac{\mu}{K} w+\rho g=\frac{\partial p}{\partial z}$

where $p$ is the fluid pressure (Pa), $g$ is the gravity acceleration $\left(\mathrm{m} \mathrm{s}^{-2}\right), u, v, w$ designate the components of the Darcy velocity $\left(\mathrm{m} \mathrm{s}^{-1}\right)$. We used the following equation of state for the air density $\rho\left(\mathrm{kg} \mathrm{m}^{-3}\right)$ :

$\rho=\rho_{0}\left(1-\alpha\left(T-T_{0}\right)\right)$

where $\rho_{0}$ and $\alpha$ are respectively the air density and the thermal expansion coefficient at the reference temperature $T_{0}$.

Neglecting density variations during transient flows, we get:

$\frac{\partial u}{\partial x}+\frac{\partial v}{\partial y}+\frac{\partial w}{\partial z}=0$

Dimensionless equations are obtained from the following scheme:

For distances, we write:

$\bar{x}=\frac{x}{L}, \quad \bar{y}=\frac{y}{L}, \quad \bar{z}=\frac{z}{L}$

For velocities:

$\bar{u}=\frac{\gamma L}{\kappa} u, \quad \bar{v}=\frac{\gamma L}{\kappa} v, \quad \bar{w}=\frac{\gamma L}{\kappa} w$

and for pressure, time and temperature, we set:

$\bar{p}=\frac{K \gamma}{\mu \kappa}\left(p-\rho_{0} g z\right), \quad \tau=\frac{L}{\kappa^{2}} t, \quad \theta=\frac{T}{\Delta T}$

where $L$ designates the thickness of the permeable layer inferred from the structure of the cone and $\Delta T$ is the bottom to top temperature difference across this layer (see Table 1 ).

Table 1

Notation and values of the physical parameters used for the convective model.

\begin{tabular}{|c|c|c|}
\hline Height of the box & $L$ & $15 \mathrm{~m}$ \\
\hline Heat capacity of the air & $c_{a}$ & $1000 \mathrm{~J} \mathrm{~kg}^{-1} \mathrm{~K}^{-1}$ \\
\hline Heat capacity of basalt & $c_{b}$ & $1000 \mathrm{~J} \mathrm{~kg}^{-1} \mathrm{~K}^{-1}$ \\
\hline Air density & $\rho$ & $1 \mathrm{~kg} \mathrm{~m}^{-3}$ \\
\hline Air thermal expansion & $\alpha$ & $3.7 \times 10^{-3} \mathrm{~K}^{-1}$ \\
\hline Air viscosity & $\mu$ & $1.5 \times 10^{-5} \mathrm{~Pa} \mathrm{~s}$ \\
\hline Thermal conductivity & $k$ & $0.4 \mathrm{~W} \mathrm{~m}^{-1} \mathrm{~K}^{-1}$ \\
\hline Air-soil volumic heat capacity ratio & $\gamma$ & $5.0 \times 10^{-4}$ \\
\hline Thermal diffusivity of the soil & $\kappa$ & $1.5 \times 10^{-7} \mathrm{~W} \mathrm{~m}^{-1} \mathrm{~K}^{-1}$ \\
\hline Gravity & $g$ & $9.81 \mathrm{~m} \mathrm{~s}^{-2}$ \\
\hline Permeability $\left(R a_{e q}=100 / 300 / 1000\right)$ & $K$ & $7 \times 10^{-8}-2 \times 10^{-7}-7 \times 10^{-7} \mathrm{~m}^{2}$ \\
\hline Top to bottom temperature contrast & $\Delta T$ & $7.5 \mathrm{~K}$ \\
\hline Geothermal heat flux & $Q$ & $200 \mathrm{~mW}$ \\
\hline Darcy velocity scale & $v$ & $2.7 \times 10^{-5} \mathrm{~m} \mathrm{~s}^{-1}$ \\
\hline
\end{tabular}


With these definitions, the dimensionless equations are:

$\frac{\partial \theta}{\partial \tau}+\bar{U} \cdot \operatorname{grad} \theta=\left(\frac{\partial \theta^{2}}{\partial \bar{x}^{2}}+\frac{\partial \theta^{2}}{\partial \bar{y}^{2}}+\frac{\partial \theta^{2}}{\partial \bar{z}^{2}}\right)$

$\frac{\partial \bar{u}}{\partial \bar{x}}+\frac{\partial \bar{v}}{\partial \bar{y}}+\frac{\partial \bar{w}}{\partial \bar{z}}=0$

$-\bar{u}=\frac{\partial \bar{p}}{\partial \bar{x}}$

$-\bar{v}=\frac{\partial \bar{p}}{\partial \bar{y}}$

$-\bar{w}+R a_{e q} \theta=\frac{\partial \bar{p}}{\partial \bar{z}}$

The vigor of the convection depends on a unique dimensionless parameter called the equivalent Rayleigh number (Antoine et al., 2009):

$R a_{e q}=\gamma \frac{K g \rho_{0} \alpha \Delta T L}{\mu \kappa}$

The variables corresponding to the SE crater are given in Table 1 . Permeability estimations of the soil range from $10^{-8}$ to $10^{-5} \mathrm{~m}^{2}$, leading to Rayleigh numbers ranging from 20 to 6000 (Antoine et al., 2009). Because of calculation limitations in 3D, we have been only able to run cases for $R a_{e q}=100,300$ and 1000 .

The dimensionless heat equation is solved with an alternative direction implicit finite difference method (Douglas and Rachford, 1956) tested by Cserepes et al. (1988), and implemented in Rabinowicz et al. (1993), Ormond et al. (1995) and Rabinowicz et al. (1998). The flow equations are solved introducing the poloidal scalar potentials in the Darcy equations. This field is then approximated in the vertical direction by finite difference and in the horizontal planes by a spectral decomposition. The reader can refer to Rabinowicz et al. (1998) for the numerical treatment of the equations.

\subsubsection{Boundary and initial conditions}

The domain of computation consists of a rectangular box with unit height and widx, widy in the $x$ and $y$ directions, respectively. Vertical faces of the domain are planes of symmetry for both the flow and the thermal field (i.e. the fluid velocity is parallel to the interfaces and there is no heat flowing across them). The bottom of the box is also impermeable and the dimensionless temperature $\theta$ is constant and equal to 1 . Along the top of the box, the dimensionless temperature $\theta$ is equal to 0 and the fluid is free to enter and leave the simulation domain. Experiments are initiated with a conductive temperature field perturbed by the product of a horizontal 2-D random function and a vertical sinusoidal function.

\subsection{The coupling between convection and $S P$}

The electrical field generated by free porous flow convection is given by Revil et al. (1999):

$E=\frac{1}{\sigma} j+C \alpha \rho_{0} g$

where $E$ is the electrical field $\left(\mathrm{V} \mathrm{m}^{-1}\right) . j$ is the macroscopic electrical current $(A)$ in the quasi-static limit:

$\nabla \cdot j=0$

The electrical field $E\left(\mathrm{~V} \mathrm{~m}^{-1}\right)$ is related to the electrical potential $\phi$ (V):

$E=\nabla \phi$

Then, the thermoelectrical equation becomes (Revil et al., 1999):

$\Delta \phi=C \alpha \rho_{0} \nabla \cdot(T g)$ a)

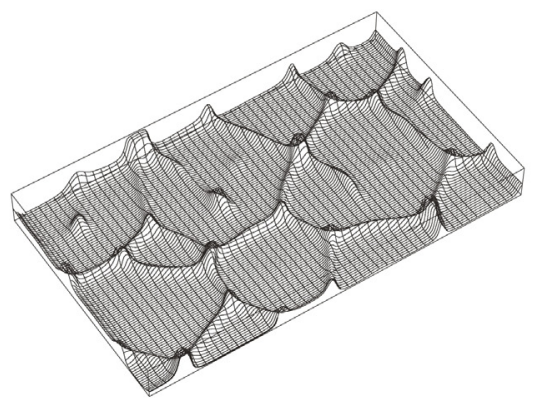

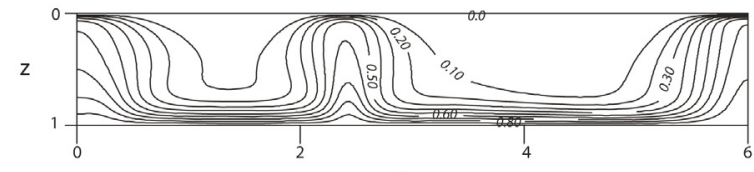

b)

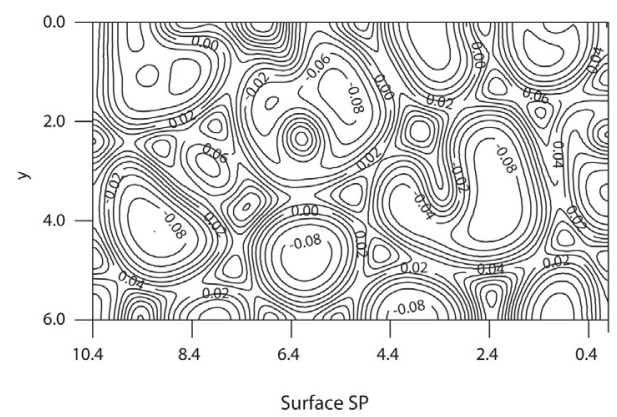

c)

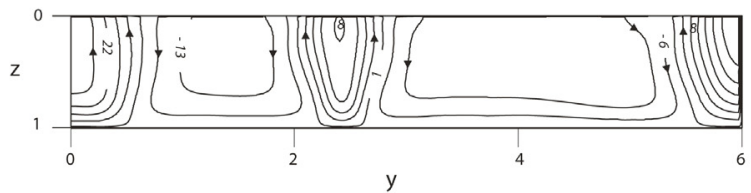

d)

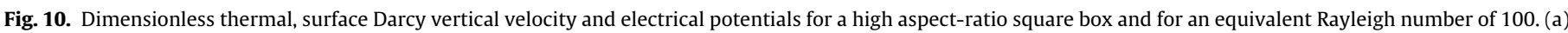

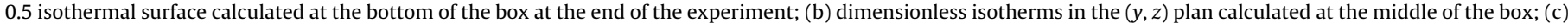

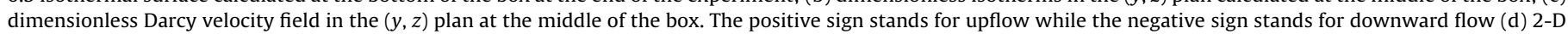
dimensionless surface SP. 
a)

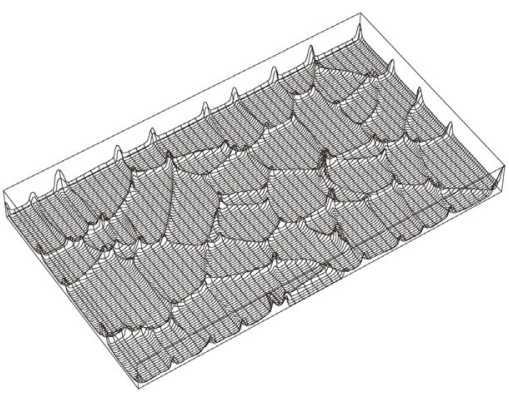

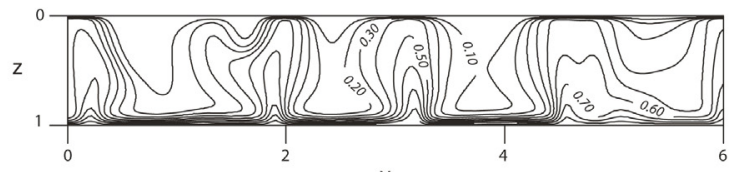

b)

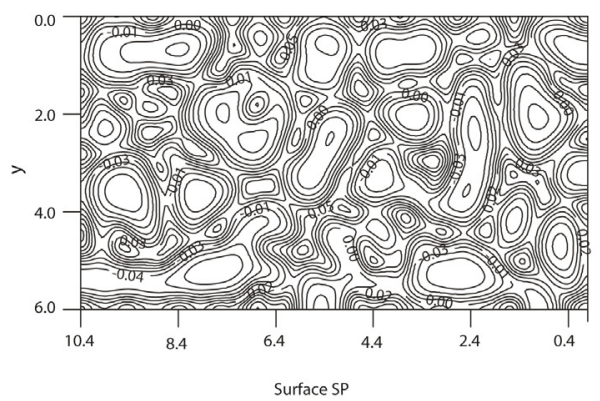

c)

d)

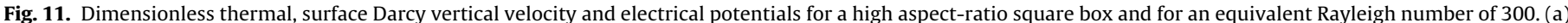

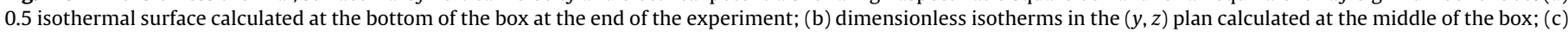

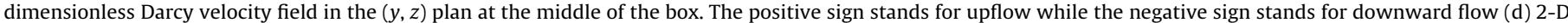
dimensionless surface SP.

Introducing the equivalent Rayleigh number in the previous equation, we obtain the following equation:

$$
\Delta \phi=\frac{C R a_{e q} \mu \kappa}{\gamma K} \nabla \cdot\left(\theta \overline{e_{z}}\right)
$$

After Fourier expansion in the horizontal direction of Eq. (29), the dimensionless electrical potential $\bar{\phi}\left(\Delta \bar{\phi}=\nabla \cdot\left(\theta \overline{e_{z}}\right)\right)$ is calculated using the following boundary conditions: $\bar{\phi}(\bar{z})=0$ on the lateral and bottom boundaries and $\delta \bar{\phi}(\bar{z}=0) / \delta \bar{z}=0$ at the top boundary.

\subsection{Numerical results}

The 3D convective pattern within Formica Leo depends on the vigour of the process and in the length to height aspect-ratio of the porous medium. In this section, we present experiments for a)

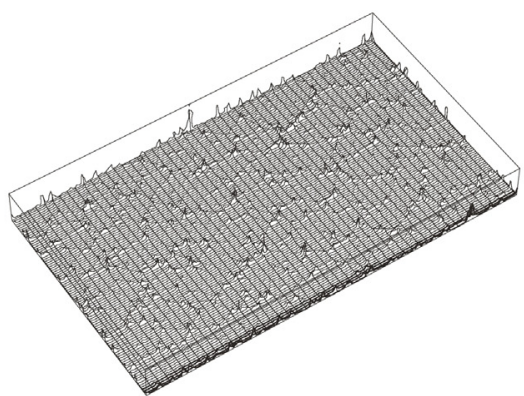

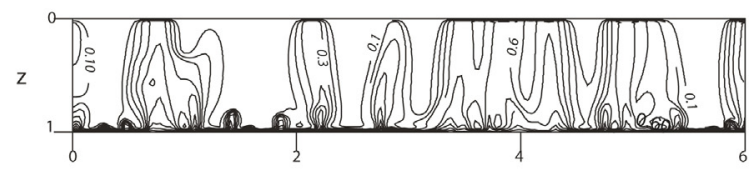

b)

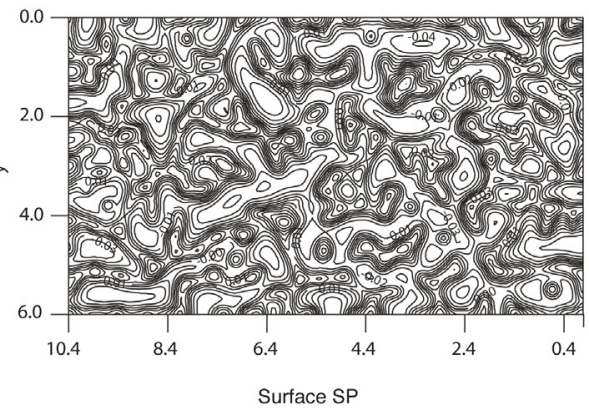

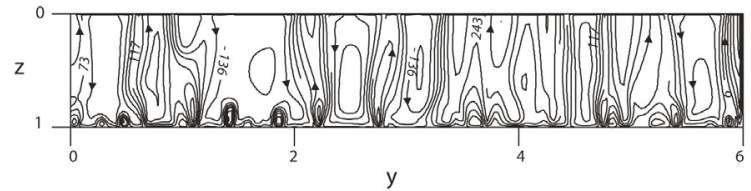

d)

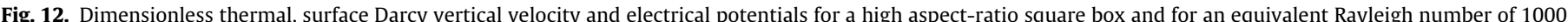

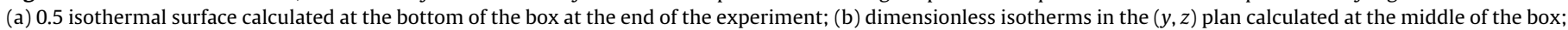

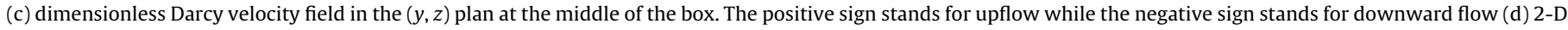
dimensionless surface SP. 
$R a_{e q}=100,300$ and 1000 and 2 aspect-ratios. The first set simulates the convection for a large aspect-ratio box (10), while the second one presents simulations in a small aspect-ratio box (1.5), similar to the one expected for one crater of Formica Leo. Such approach leads to the characterization of the influence of the different boundaries of the cone on the development of the convective cells.

\subsubsection{Experiments within a large aspect-ratio box}

Figs. 10-12 show 3-D numerical simulations developed in a large aspect ratio box (equal to 10). Figs. 10a, 11a and 12a display the corresponding 0.5 dimensionless isotherm snapshot taken at the end of the experiment for an equivalent Rayleigh number of $R a_{e q}$ $=100,300$ and 1000, respectively. 3 -D polygonal cells develop. Hot flows localize along the walls of the cells and the cold dipping flows are diffuse and follow the cell axis (Figs. 10b, 11b and 12b, respectively). From $R a_{e q}=100$ to 300 , the hexagonal cell size decreases, and from 300 to 1000 , the flow becomes unsteady. Hot plumes are generated along the lower boundary layer and advected within the upwelling limb of the convective cells. In the same way, the temperature contrast between hot and cold areas increases (from 0.2 to 0.5 , see Table 2 ). Figs. $10 \mathrm{c}, 11 \mathrm{c}$ and $12 \mathrm{c}$ present the vertical velocity at the top of the box. The amplitude of the vertical velocity linearly increases with $R a_{e q}$. Fig. $10 \mathrm{~d}, 11 \mathrm{~d}$ and $12 \mathrm{~d}$ display the isolines of the dimensionless electrical potential at the top of the box. Downward flows correlate with negative values of $\bar{\phi}$, while ascending plumes correspond to positive values. Note that the spacing of the isolines across the ascending and descending flows become narrower as the Rayleigh number increases. The difference between the
Table 2

Dimensionless (d.) and real values for the temperature $T\left({ }^{\circ} \mathrm{C}\right)$, vertical ascending and descending velocities $V_{u}$ and $V_{d}\left(\mathrm{~m} \mathrm{~s}^{-1}\right)$, respectively, and electrical potentials SP (V). The real values have been calculated with the parameters of Table 6 .

\begin{tabular}{rllrlrlll}
\hline$R a_{e q}$ & $d . T$ & $T$ & $d . V_{u}$ & $V_{u}$ & $d . V_{d}$ & $V_{d}$ & $d . S P$ & SP \\
\hline 100 & 0.2 & 1.5 & 22 & $5 \times 10^{-4}$ & -8 & $2 \times 10^{-4}$ & 0.1 & 1 \\
300 & 0.4 & 3 & 43 & $10^{-3}$ & -29 & $7 \times 10^{-4}$ & 0.04 & 0.6 \\
1000 & 0.5 & 3.75 & 243 & $6 \times 10^{-3}$ & -136 & $4 \times 10^{-3}$ & 0.06 & 0.5
\end{tabular}

maxima and the minima of the dimensionless electrical signal decreases to $0.1,0.04$ and 0.06 for $R a_{e q}=100,300$ and 1000, respectively. The decrease by a factor of two of the electrical signal between $R a_{e q}=100$ and 300 model is related to the decrease of the size of the cells. The small increase of amplitude of the electrical signal for the $R a_{e q}=1000$ experiment is related to the presence of hot instabilities advected inside the convective cells.

\subsubsection{Experiments within a small aspect-ratio square box}

Figs. 13-15 show simulations in boxes with an aspect ratio of 1.5 . The 0.5 isotherm shows the development of a single steady state square cell at $R a_{e q}=100$ and 300, respectively (Figs. 13a and 14a). A unique single cell develops with a diffuse downwelling and several upwellings located along the boundaries of the box (Figs. 13a and 14a). The back flow driven by these plumes also follows the boundaries of the box. More precisely, when $R a_{e q}=100$, there are four hot plumes at each corner of the box and two back flows in between them. When $R a_{e q}=300$, a new plume develops along one side wall, while four 'cold' return flows localize along the different vertical
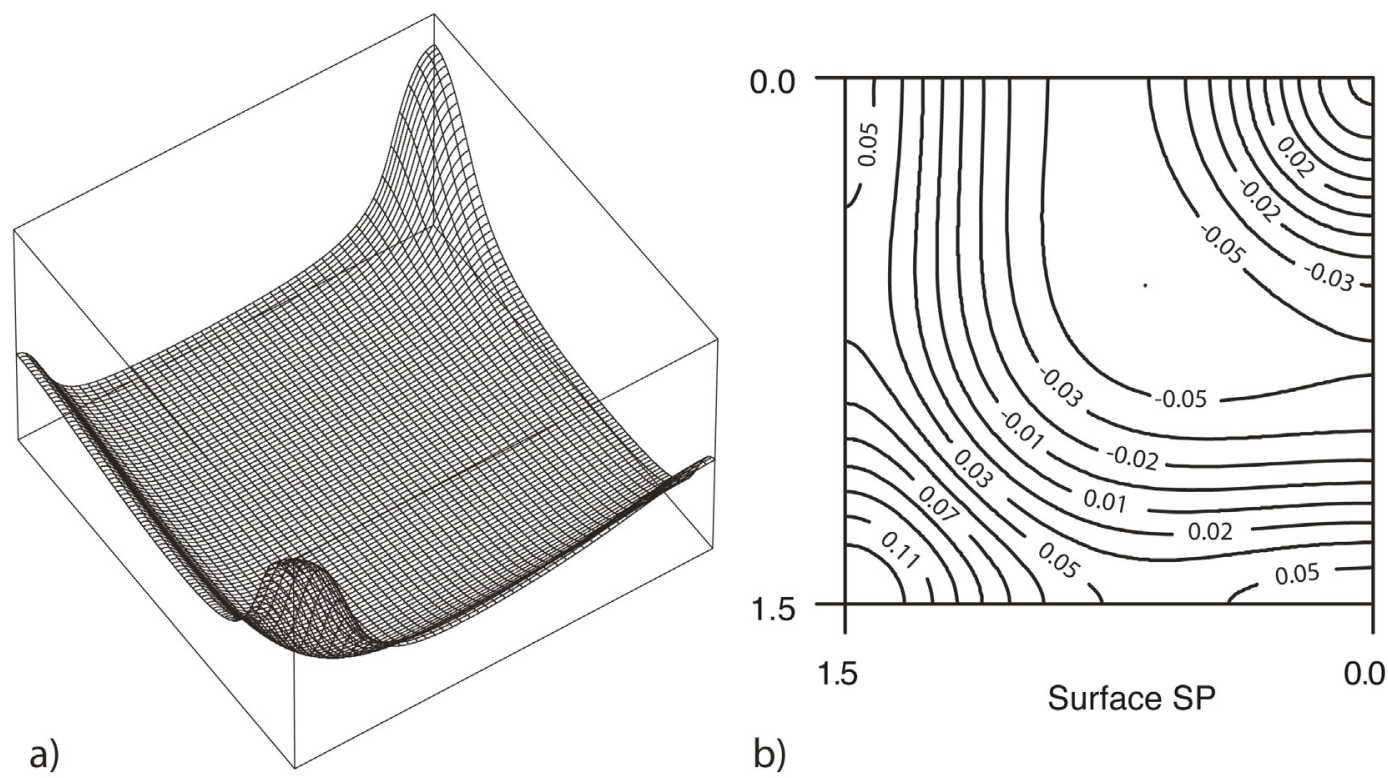

b)

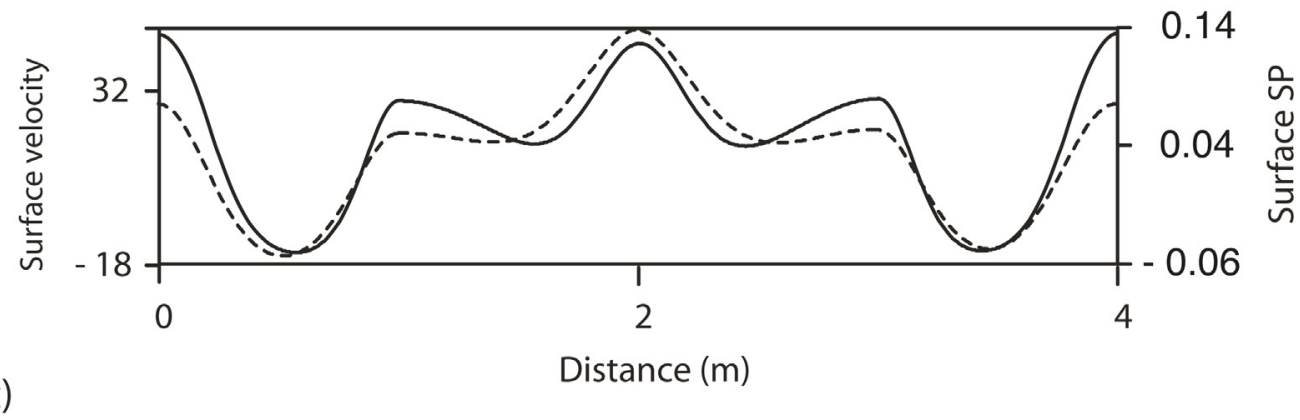

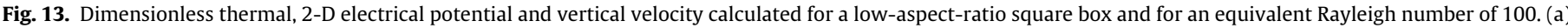

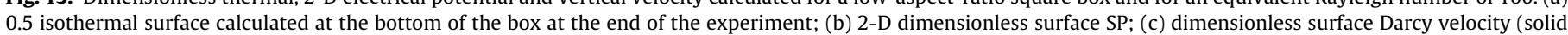
line) and SP signal (dashed line) generated by the flow along the boundaries of the box. 

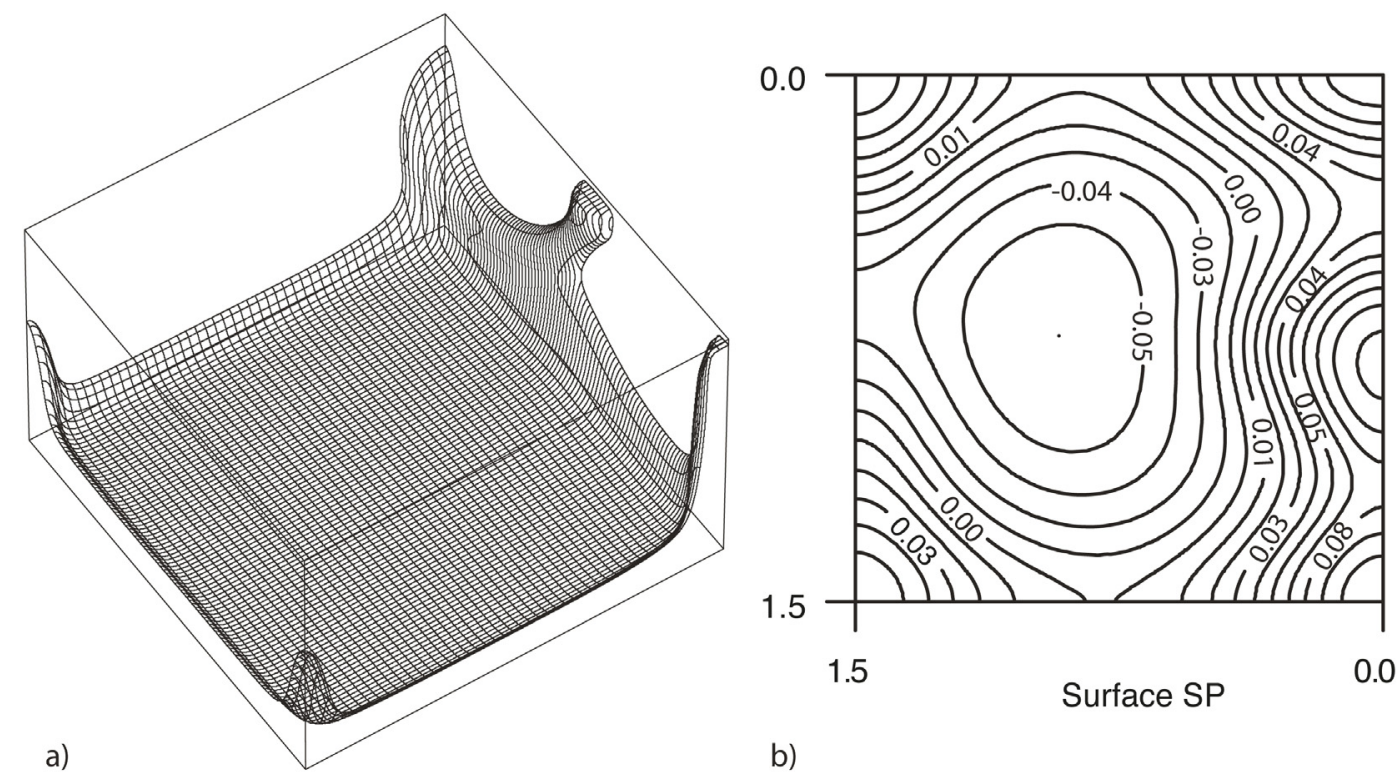

b)

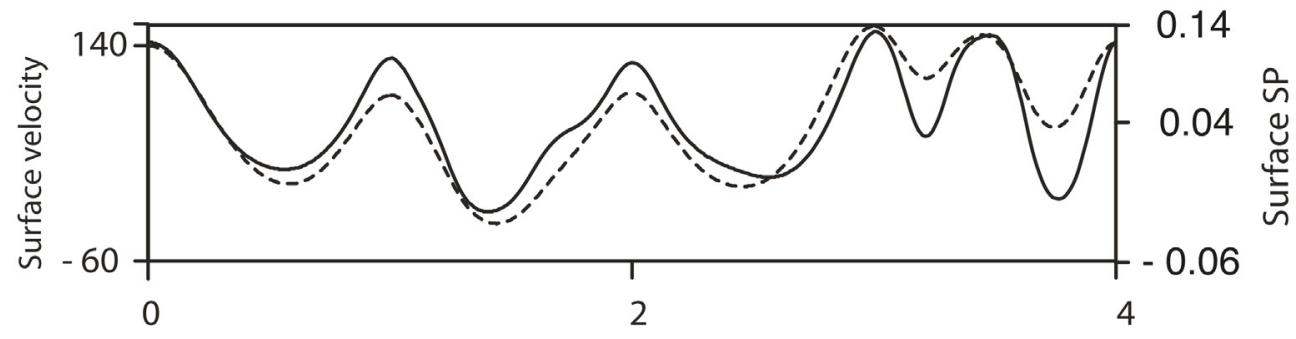

c)

Distance $(m)$

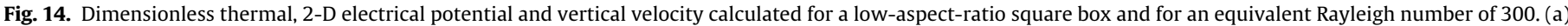

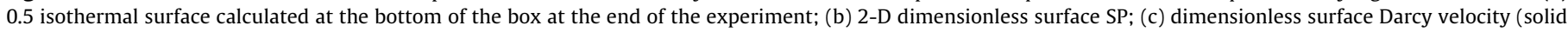
line) and SP signal (dashed line) generated by the flow along the boundaries of the box.

boundaries. When $R a_{e q}=1000$, several small size unsteady polyhedral structures develop (Fig. 15a). Note that $R a_{e q}=100$ and 300 experiments capture the essential features deduced from the geophysical survey, i.e. a diffuse cold central downwelling and warm plume and mild return flows along the rims of the craters. The $R a_{e q}$ $=1000$ experiment is not acceptable because it exhibits hot plumes inside the crater, which are not apparently found at Formica Leo. Indeed, there are two phenomena which are able to stabilize cold downwellings at the center of the crater: (i) a small length over height aspect ratio; (ii) a radial tilt of the soil from the center to the rim of the crater. Note that for Rayleigh number up to 300, the first effect is enough to stabilize the downwellings while the second effect is required when the Rayleigh number is from 1000 to 6000 (Antoine et al., 2009).

Figs. 13b, 14b and 15b present the electrical signal at the top of the box. Negative values are found at air downflows and positive values over upflows. Again, the dimensionless amplitudes of the electrical signal are $0.2,0.2$ and 0.1 when $R a_{e q}=100,300$ and 1000, respectively (Figs. 13b-15b). Figs. 13c, 14c and 15c compare the vertical velocity and the SP signal generated by upflows and downflows along the boundaries of the box. As the intensity of convection rises, the vertical velocity increases, enhancing the heat transfer. Minimum dimensionless downflow velocities are -18 , -30 and $-150\left(5 \times 10^{-4} \mathrm{~m} \mathrm{~s}^{-1}, 8 \times 10^{-4} \mathrm{~m} \mathrm{~s}^{-1}\right.$ and $4 \times 10^{-3} \mathrm{~m} \mathrm{~s}^{-1}$, see Table 3 ) for $R a_{e q}=100,300$ and 1000, respectively. Maximum dimensionless upflow velocities reach $32\left(10^{-3} \mathrm{~m} \mathrm{~s}^{-1}\right.$, see Table 3$)$, $140\left(4 \times 10^{-3} \mathrm{~m} \mathrm{~s}^{-1}\right)$ and $350\left(10^{-2} \mathrm{~m} \mathrm{~s}^{-1}\right)$, respectively. The electrical signal correlates well with the air velocity. In fact, the electrical
Table 3

Dimensionless $(d$.) and real values for vertical ascending and descending velocities $V_{u}$ and $V_{d}\left(\mathrm{~m} \mathrm{~s}^{-1}\right)$, respectively, and electrical potentials SP $(\mathrm{V})$. The real values have been calculated with the parameters of Table 6 .

\begin{tabular}{rrlrlll}
\hline$R a_{e q}$ & $d . V_{u}$ & $V_{u}$ & $d . V_{d}$ & $V_{d}$ & $d . S P$ & $S P$ \\
\hline 100 & 32 & $10^{-3}$ & -18 & $5 \times 10^{-4}$ & 0.2 & 0.1 \\
300 & 140 & $4 \times 10^{-3}$ & -30 & $8 \times 10^{-4}$ & 0.2 & 0.1 \\
1000 & 350 & $10^{-2}$ & -150 & $4 \times 10^{-3}$ & 0.1 & 0.05 \\
\hline
\end{tabular}

signal acts as a lowpass filter of the temperatures (Eqs. (29) and (19)). This explains why the SP signal is smoother than the surface temperature in our model. Moreover, this characteristic of the SP signal can be observed in the field (Finizola et al., 2003). Comparison of the amplitude of the electrical signal with those of the large box experiment suggests the following. First, when $R a_{e q}=100$ or 300 , the convective cell occupies the entire box, and thus has a size exceeding that of the large aspect ratio experiment. Consequently, this fixes the dimensionless amplitude of the electrical signal to 0.2 instead of 0.1 and 0.04 for the corresponding large box experiment. This effect is still observed for the $R a_{e q}=1000$, explaining why the dimensionless amplitude of the electrical signal reaches 0.1 instead of 0.06 . However, a value of the SP amplitude of 0.2 would be expected in case where the $R a_{e q}=1000$ experiment would be realized in a tilted box, because in this case, air enters the box downwards and rises upwards. Thus, the dimensionless contrast between the downflow and the upflow can be estimated at about 0.2 for all $R a_{e q}$. The amplitude of the electrical contrast in the field 

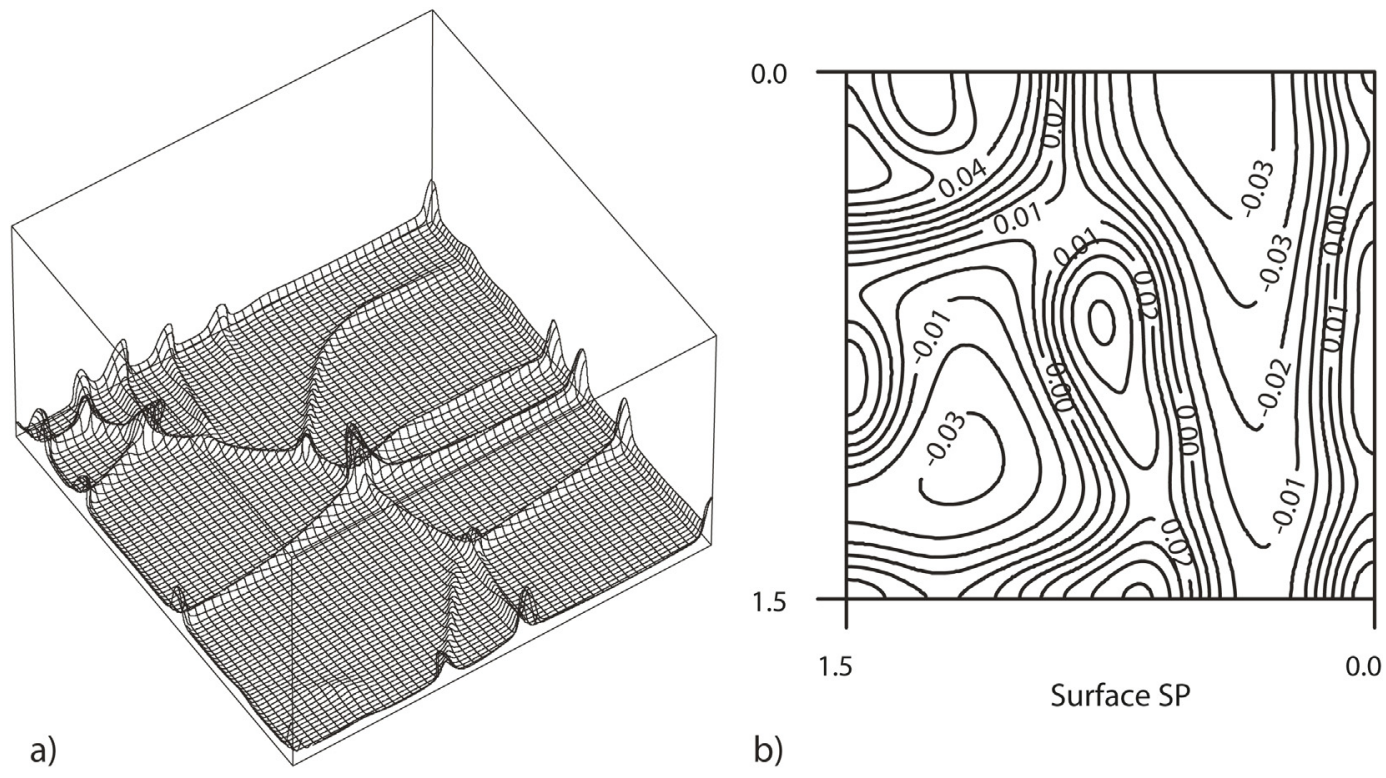

b)

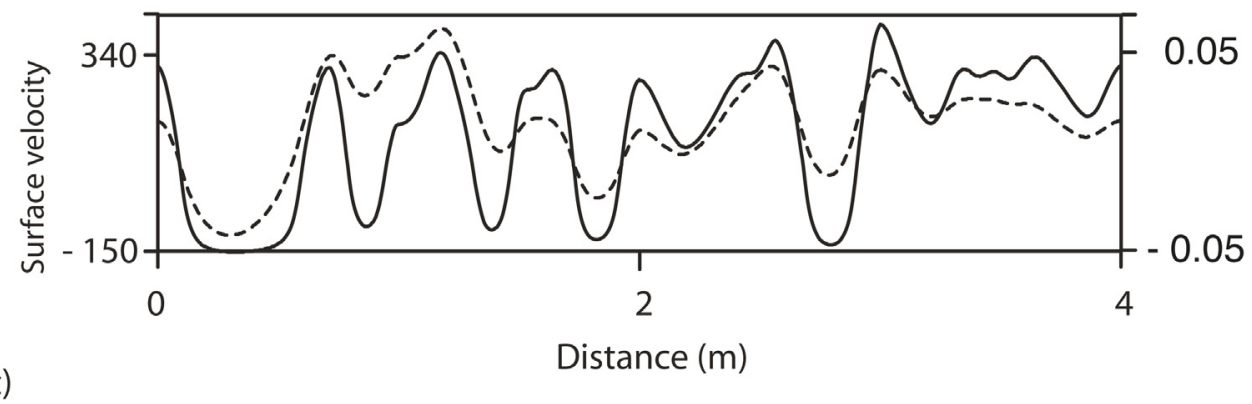

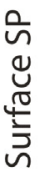

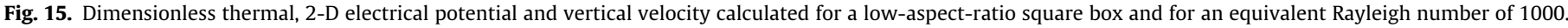

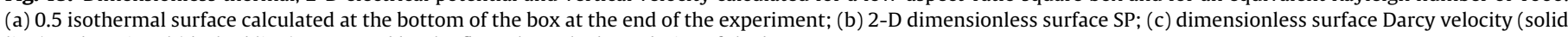
line) and SP signal (dashed line) generated by the flow along the boundaries of the box.

can be calculated by multiplying the dimensionless signal by (Eq. (29)):

$$
\frac{C R a_{e q} \mu \kappa}{\gamma K}
$$

Note that because of the linear dependance of $R a_{e q}$ with $K$, the later expression is independent of this parameter. Thus, it is not affected by the large uncertainty on the permeability amplitude. Besides, the free parameters determining the Rayleigh number are $\Delta T, L$ and $k$. Indeed, $\Delta T=(Q \times L) / k$, where $Q$ represents the average regional geothermal heat flux $\left(200 \mathrm{~mW} \mathrm{~m}^{-2}\right)$. It implies that the only parameter which can significantly modify the amplitude of the SP signal is the height $L$ of the convective zone. The latter quantity being determined by the GPR and the microgravimetry analysis, the amplitude of the SP anomaly just depends on the value of $C$. Taking $C \approx 0.145 \mathrm{~V} \mathrm{~Pa}^{-1}$ for a porous medium composed of humid air (Section 3.3.1), a SP anomaly of $0.157 \mathrm{~V}$ is derived, a value in good agreement with the observations (Tables 1 and 3 ).

\section{Discussion}

Our study leads to the quantification of the relationship between the electrical potential and the unsaturated convection in a highly permeable volcanic zone. Our work follows the basic approach of Ishido and Pritchett (1999). These authors have modeled a $2 \mathrm{~km}$ high saturated convective flow, It is seen to induce a $200 \mathrm{mV}$ SP anomaly over a horizontal distance of $2 \mathrm{~km}$. Considering that the Rayleigh number for their experiments $\left(R a_{e} q / \gamma\right) \approx 100$, our results are directly comparable. The similarity between both models results from a coupling coefficient $C$ of $10^{-7} \mathrm{~V} \mathrm{~Pa}^{-1}$ (instead of $0.1 \mathrm{~V} \mathrm{~Pa}^{-1}$ for us), a viscosity 50 times smaller at $300^{\circ} \mathrm{C}$ than at $25^{\circ} \mathrm{C}$ and a permeability of $10^{-14} \mathrm{~m}^{2}$ (instead of $10^{-7} \mathrm{~m}^{2}$ for us). Accordingly, both models agree provided that the coupling coefficient is 6 orders of magnitude smaller in the saturated case considered by Ishido and Pritchett (1999). Actually, considering a factor 50 between the two viscosities, 2 orders of magnitude due to the resistivities, a factor 2 due to the difference in porosity ( 0.4 for this study and 0.2 for Ishido and Pritchett (1999)) (Eq. (3)) and 2 orders of magnitude due to the water saturations (Eq. (4)), we explain the 6 orders of magnitude difference in the amplitude between both $C$ coefficients. If this rule of thumb justifies our results, it remains that it needs to be intuitively explained. When the porous medium is saturated with water, the electrical signal depends on $\sigma_{w}$ and is induced by the movement of ions in the pores. In the unsaturated medium composing Formica Leo, we propose that the SP signal is generated by the movement of the water films coating the rock, being dragged by the rapid subsurface humid airflow. The amplitude of the SP signal is inversely proportional to the electrical conductivity (Section 3.3.1), which is much smaller in our case than in the saturated case. At Formica Leo, the presence of liquid films coating the rock is primordial, as airflow cannot generate SP by its own. This hypothesis is substantiated by the measurement of erratic SP signals during summer, i.e. when the soil of the cone is dry.

May our results at Formica Leo be applicable to air convection affecting the whole structure of PdF volcano? Several studies 


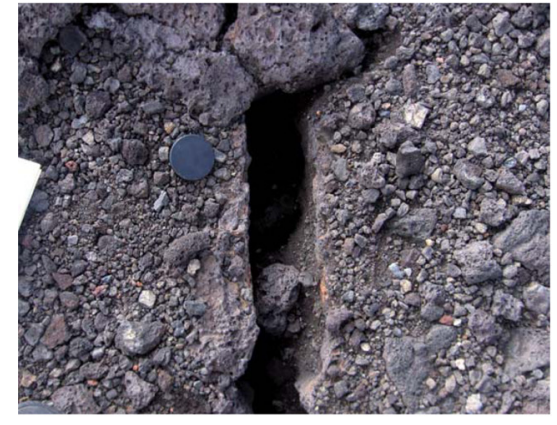

a )

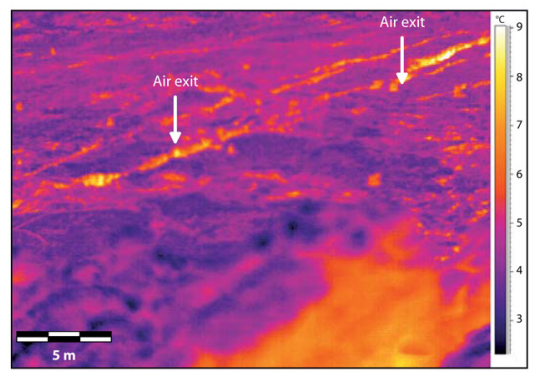

c)

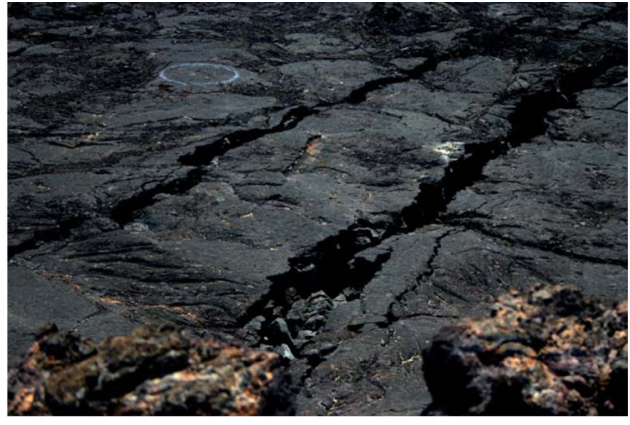

b)

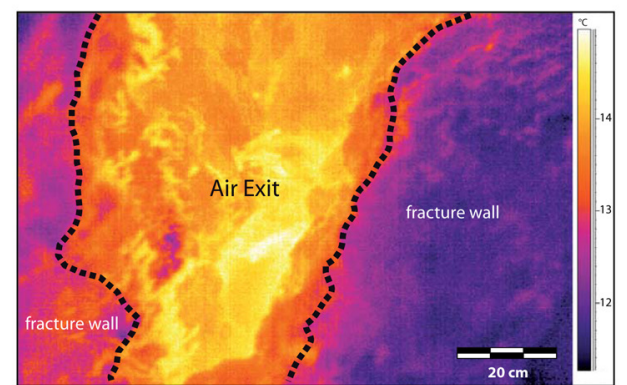

d)

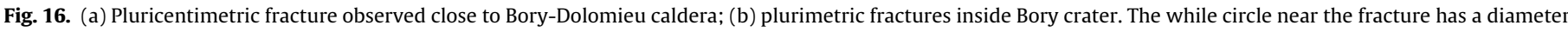

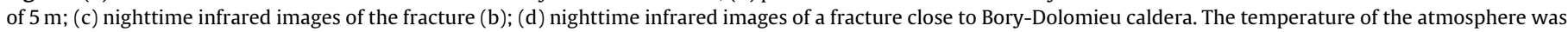
$4{ }^{\circ} \mathrm{C}$ during the acquisition ( 4 a.m.).

suggest that pluri-kilometric subsurface airflow can occur within both active or inactive volcanic structures (Weeks, 1987; Ross et al., 1992; Lu et al., 1999; Ohsawa et al., 2000; Antoine et al., 2011; Lopez et al., 2012). In fact, the structure of PdF is not so different from the structure of Formica Leo. Most eruptions lead to the formation of scorias and cinders layers (similar to Formica Leo) as well as lava flows advancing down the volcano flanks, eventually leading to lava tubes. Thus, PdF volcano is made up with a sequence of permeable layers (scorias, fractured lava flows, tubes, breccias) and impermeable layers (cinders, tuffaceous soils or massive pahoehoe).

Several studies suggest that PdF moving Eastward generates radial and concentric fractures (Bachelery, 1981; Labazuy, 1996; Merle and Lénat, 2003), in which recurrent intrusions take place. Accordingly, this fracturation is not homogeneous, and is very extensive in the South and North of Dolomieu collapse.
Such fractures have a maximum depth in the range $300-800 \mathrm{~m}$ (Gudmundsson et al., 1992), depending of their distance from the crater. This process confers to the edifice an excellent vertical permeability in the zones of extension (i.e. the occidental part of the volcano and the terminal cone, see Fig. 16). Thereafter, the oriental flank accumulates the strength associated to the displacement of the volcano, leading to a compression which reduces the vertical permeability. Finally, the scoria layers impose a strong horizontal permeability. According to the estimation given in Antoine et al. (2009), it is likely to assign a permeability value $7 \times 10^{-8} \mathrm{~m}^{2}$ to this layer. Now, if we consider that the volcanic structure is composed of $15 \%$ of breccias and of $85 \%$ of dense horizontal layers, the bulk horizontal permeability of the volcano may drop to $1.8 \times 10^{-8} \mathrm{~m}^{2}$. Actually, the measured conductivity of the soils of Piton de la Fournaise is $0.4 \mathrm{~W} \mathrm{~m}^{-1} \mathrm{~K}^{-1}$ (Table 1 , (Antoine et al., 2009)) and the

W

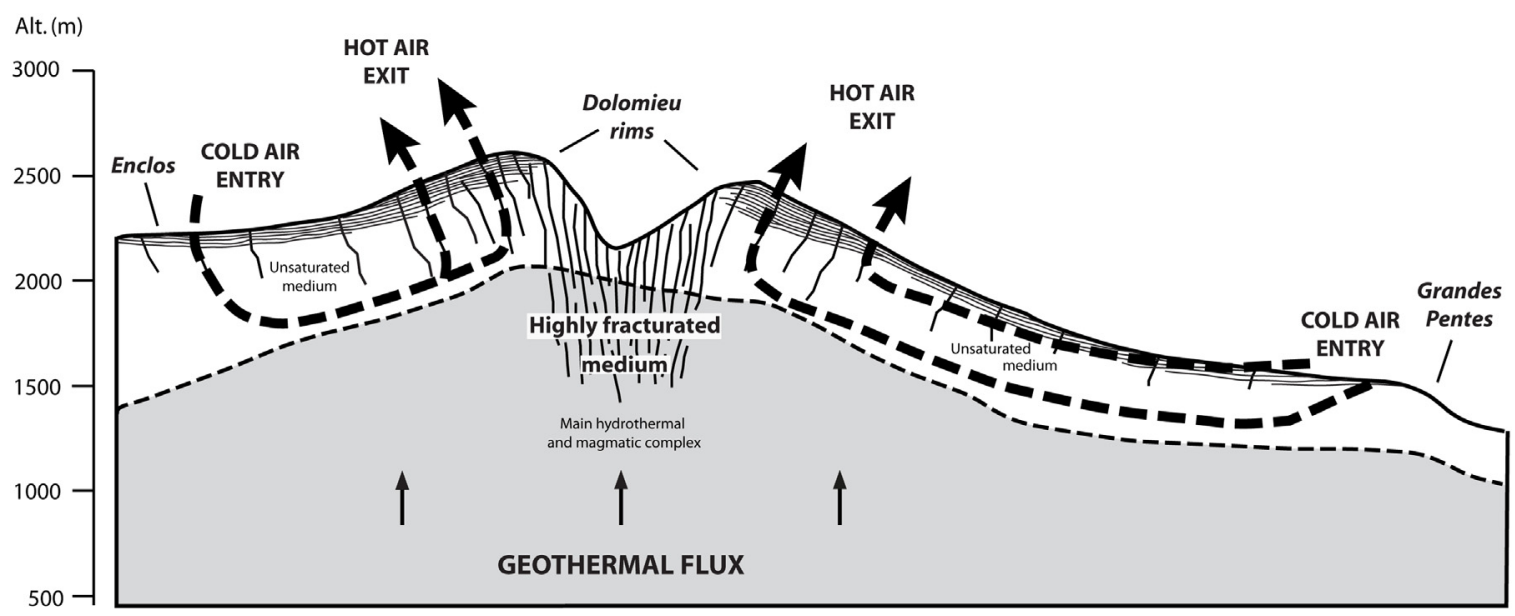

Fig. 17. Sketch of the subsurface airflow through Piton de La Fournaise volcano. Internal structure of the volcano from Lénat et al. (2000). 
thermal conductivity of the dense layer is $2.4 \mathrm{~W} \mathrm{~m}^{-1} \mathrm{~K}^{-1}$. The effective thermal conductivity of the horizontal layers is $2 \mathrm{~W} \mathrm{~m}^{-1} \mathrm{~K}^{-1}$. It leads to a thermal diffusivity of $3.7 \times 10^{-7} \mathrm{~m}^{2} \mathrm{~s}^{-1}$.

At PdF volcano, the topographic slopes range from less than $5^{\circ}$ near Enclos Fouqué cliff to more than $20^{\circ}$ at the flanks of the terminal cone (Michon et al., 2007). Because of the high horizontal permeability, the slope triggers an intense air convection (Genthon et al., 1990). The cold air enters the volcano in its occidental part within both open vertical fractures and horizontal permeable Breccia layers, while in its oriental part, it is exclusively confined within the horizontal permeable layers (Fig. 17). Within the volcano, the air is heated by the geothermal gradient $\left(200 \mathrm{~mW} \mathrm{~m}^{-2}\right)$, flows upslope through the permeable layers and exits through the vertical network of fractures around the Dolomieu collapse. In our global air convection model, we consider a height $L$ of $700 \mathrm{~m}$ for the convective layer, i.e. nearly $400 \mathrm{~m}$ under the actual bottom of Dolomieu collapse. Such a thickness is compatible with the high-resistivity $(8-100 \mathrm{k} \Omega$ ) layers found by Lénat et al. (2000), which may correspond to unsaturated porous basalts. Considering a $200 \mathrm{~mW} \mathrm{~m}^{-2}$ heat flux for PdF volcano, corresponding to a temperature contrast of $70^{\circ} \mathrm{C}$ across the unsaturated layer, an equivalent Rayleigh number of 300 is derived for air convection. As a consequence, the 3-D numerical model of Fig. 13 gives a first order picture of the dimensionless thermal and flow fields along with the dimensionless surface electrical anomalies through the whole volcano.

The peak to bottom SP anomaly at PdF has an amplitude of $2 \mathrm{~V}$ (Fig. 2). Also, the exit temperature at the caldera is expected to reach $14^{\circ} \mathrm{C}$, a value similar to the nighttime infrared temperatures we measured along the hot fractures next to Dolomieu (Fig. 16). Finally, the exit Darcy velocity is $10^{-4} \mathrm{~m} \mathrm{~s}^{-1}$. This velocity is clearly unmeasurable, but some areas, for instance opened fractures, may locally drive the main Darcy flow occupying the wide exit zone, and thus be high enough to be detected by ultrasonic anemometry.

\section{Conclusion}

Formica Leo scoria cone has been found to be a natural laboratory to study the air convection in a permeable volcanic soil as well as its consequences on the thermal field and the electric potentials. Field data (infrared thermography, SP, GPR and microgravimetry) have been acquired to estimate the values of the different parameters relevant to model the air convection within Formica Leo. This analysis supports a possible range of equivalent Rayleigh numbers $\mathrm{Ra}_{e q}$ from 20 to 6000 , and lead us to calculate a 3-D model of the humid air convection within the soil of Formica Leo.

The three-dimensional models were run using two different length to height aspect-ratios, one of 10 and the other of 1.5 , the latter being comparable with the geometry of Formica Leo. Models with $R a_{e q}$ ranging from 100 to 300 show the essential features of the air convection deduced from the geophysical survey: i.e. a large diffuse downflow at the axis of the craters and several upflows and return flows along their rims. Moreover, a surface SP map explaining both the amplitude and the shape of the field observations is computed, using a coupling coefficient 6 orders of magnitudes higher than that of a soil saturated with water (i.e. in the range of the possible estimations for air convection in a humid porous media). Models at a higher Rayleigh number display unsteady flows consisting of a large number of small size hexagons. This proves that for a high Rayleigh number, the confining effect due to the small horizontal extent of the craters is not strong enough to confine the diffuse dipping flow within the center of the structure. However, our 2-D modeling in Antoine et al. (2009) shows that the bottom to rim tilting of the cone, which has not been taken into account in our present 3-D calculations, will stabilize the central dipping current. Interestingly, the dimensionless contrast between peaks and lows of the electric field for the models with a 1.5 length to height ratio convective cells expected for Formica Leo is 0.2 . This set of results shows that the peak to bottom SP anomaly equals:

$0.2 \times \frac{g^{2} \rho^{2} \epsilon_{f} \zeta \alpha Q L^{2}}{\eta_{f} k \sigma_{f}}$

Considering the high complexity of the global permeable network of Piton de la Fournaise volcano, in which the large scale air convection takes place, we only look for a first order agreement between our models and observed SP anomalies. Structural data indicate that the horizontal permeability of the volcano results from the presence of a sequence of permeable and dense layers, while the vertical one is induced by open fractures concentrated under BoryDolomieu caldera and the western flank. This leads us to propose that the air essentially enters via open fractures in the occidental flank and via horizontal layers in its occidental part. Then, it moves up across the $700 \mathrm{~m}$ thick unsaturated layer up to the vertical network below the caldera (Fig. 17). Estimations of the various parameters pertaining to this air convection lead to predict an air exit temperature of $14^{\circ} \mathrm{C}$ and a caldera to flank SP anomaly of $2.3 \mathrm{~V}$, in good agreement with observations. An increase of the amplitude SP anomaly is recorded before and after an eruption. Considering Eq. (31), it is inferred that the effective height of the air convection in Piton de la Fournaise is proportional to the square of the rate of increase of the SP anomaly. Before an eruption, the inflation of the volcano due to pressure in the magma chamber may lead to an increase of the permeability of the deep parts of the structure, thus increasing the thickness of the convective layer. Our results could be used in the future to estimate the geometrical characteristics of this layer prior to eruption.

\section{Acknowledgements}

This work was funded by Région Réunion and ANR Volcarisk. We thank M. Huet, L. Souprayen, N. Rasendra, N. Andrianarimalala, M. Begue, and J. Pisentie for the help in the field during the electric resistivity tomography campaign, as well as Emilie Roulleau and Nicolas Vinet for their constructive comments. The work of Anthony Finizola, Eric Delcher, Fabrice R. Fontaine, and Thomas Staudacher is an IPGP contribution number 3203.

\section{References}

Adler, P., Thovert, J.-F., 2010. Under the volcano: unsaturated flow and induced variations of electromagnetic and gravitational fields. Transp. Porous Media 83 219C232, http://dx.doi.org/10.1007/s11242-009-9471-5.

Aizawa, K., 2008. Classification of self-potential anomalies on volcanoes and possible interpretations for their subsurface structure. J. Volcanol. Geotherm. Res. 175, 253-268, http://dx.doi.org/10.1016/j.jvolgeores.2008.03.011.

Allègre, V., Maineult, A., Lehmann, F., Lopes, F., Zamora, M., 2014. Self-potential response to drainage imbibition cycles. Geophys. J. Int. 197, 1410-1424, http:// dx.doi.org/10.1093/gji/ggu055.

Antoine, R., Baratoux, D., Rabinowicz, M., Fontaine, F., Bachèlery, P., Staudacher, T., Saracco, G., Finizola, A., 2009. Thermal infrared image analysis of a quiescent cone on Piton de la Fournaise volcano: evidence of convective within an unconsolidated soil. J. Volcanol. Geotherm. Res. 183, 228-244, http://dx.doi. org/10.1016/j.jvolgeores.2008.12.003.

Antoine, R., Lopez, T., Baratoux, D., Rabinowicz, M., Kurita, K., 2011. Thermal analysis of fractures at Cerberus Fossae, Mars: detection of air convection in the porous debris apron. Icarus 214 (2), 433-446, http://dx.doi.org/10.1016/j icarus.2010.12.025.

Antraygues, P., Aubert, M., 1993. Self-potential generated by two-phase flow in a porous medium: experimental study and volcanological applications. J. Geophys. Res. 98 (B12), 22273-22281, http://dx.doi.org/10.1029/93JB02395.

Archie, G.E., 1942. The electrical resistivity log as an aid in determining reservoir characteristics. Trans. Am. Inst. Mining Metall. Eng. 146, 54-62.

Aubert, M., Atangana, Q., 1996. Self-potential method in hydrogeological exploration of volcanic areas. Ground Water 34 (6), 1010-1016, http://dx.doi. org $/ 10.1111 / \mathrm{j} .1745-6584.1996 . t b 02166 . x$.

Aubert, M., Dana, I., Gourgaud, A., 2000. Internal structure of the Merapi summit from self-potential measurements. J. Volcanol. Geotherm. Res. 100, 337-343, http://dx.doi.org/10.1016/S0377-0273(00)00143-8. 
Aubert, M., Auby, R., Bourlet, F., Bourlet, Y., 1984. Contribution à la surveillance de l'activité de l'Etna à partir de l'étude des zones fumerolliennes. Bull. Volcanol. 47, 1039-1050, http://dx.doi.org/10.1007/BF01952359.

Awdankiewicz, M., 2004. Sedimentation, volcanism and subvolcanic intrusions in a late Palaeozoic intramontane trough (the Intra-Sudetic Basin, SW Poland). Geol. Soc. Lond. Spec. Publ. 234, 5-11, http://dx.doi.org/10.1144/GSL.SP.2004. 234.01.02.

Bachèlery, P., 1981. Le Piton de la Fournaise (Ile de la Réunion): Etude volcanologique, structurale et pétrologique (Ph.D. thesis). Université Clermon Ferrand II.

Barde-Cabusson, S., Finizola, A., Peltier, A., Chaput, M., Taquet, N., Dumont, S., Duputel, Z., Guy, A., Mathieu, L., Saumet, S., Sorbadre, F., 2012. Structural control of collapse events inferred by self-potential mapping on the Piton de la Fournaise volcano (La Runion Island). J. Volcanol. Geotherm. Res. 209-210, 9-18, http://dx.doi.org/10.1016/j.jvolgeores.2011.09.014.

Bedrosian, P., Unsworth Martyn, J., Johnston Malcolm, J., 2007. Hydrothermal circulation at Mount St. Helens determined by self-potential measurements. J. Volcanol. Geotherm. Res. 160 (1-2), 137-146, http://dx.doi.org/10.1016/j. jvolgeores.2006.09.003.

Birch, F., 1993. Testing Fournier's method for finding water table from self-potential. Ground Water 31, 50-56, http://dx.doi.org/10.1111/j.17456584.1993.tb00827.x.

Bonvalot, S., Diament, M., Gabalda, G., 1998. Continuous gravity recording with Scintrex CG-3M meters: a promising tool for monitoring active zones. Geophys. J. Int. 135, 470-494, http://dx.doi.org/10.1046/j.1365-246X.1998.00653.x.

Brothelande, E., Finizola, A., Peltier, A., Delcher, E., Komorowski, J.-C., Di Gangi, F., Borgogno, G., Passarella, M., Trovatoe, C., Legendre, Y., 2014. Fluid circulation pattern inside La Soufrire volcano (Guadeloupe) inferred from combined electrical resistivity tomography, self-potential, soil temperature and diffuse degassing measurements. J. Volcanol. Geotherm. Res. 288, 105-122, http://dx. doi.org/10.1016/j.jvolgeores.2014.10.007.

Cserepes, L., Rabinowicz, M., Rosemberg-Borot, C., 1988. Three-dimensional infinite Prandl number convection in one and two layers with implications for the Earth's gravity field. J. Geophys. Res. 93, 12009-12025, http://dx.doi.org/ 10.1029/JB093iB10p12009.

Darnet, M., Marquis, G., 2004. Modelling streaming potential (SP) signals induced by water movement in the vadose zone. J. Hydrol. 285, 114-124, http://dx.doi org/10.1016/j.jhydrol.2003.08.010.

Douglas, J., Rachford, $\mathrm{H}_{\mathrm{w}}$ 1956. On the numerical simulation of the heat conduction problem in two and three space variables. Trans. Am. Math. Soc. 82, 421-439.

Finizola, A., Sortino, F., Lénat, J.-F., Valenza, M., 2002. Fluid circulation at Strombol volcano (Aeolian Islands, Italy) from self-potential and soil gas surveys. J. Volcanol. Geotherm. Res. 116 (1-2), 1-18, http://dx.doi.org/10.1016/S03770273(01)00327-4.

Finizola, A., Sortino, F., Lénat, J.-F., Aubert, M., Ripepe, M., Valenza, M., 2003. The summit hydrothermal system of Stromboli. New insights from self-potential, temperature, $\mathrm{CO}_{2}$ and fumarolic fluid measurements, with structural and monitoring implications. Bull. Volcanol. 65, 486-504, http://dx.doi.org/10. 1007/s00445-003-0276-z.

Finizola, A., Lénat, J., Macedo, O.D.R., Thouret, J.-C., Sortino, F., 2004. Fluid circulation and structural discontinuities inside Misti volcano (Peru) inferred from self-potential measurements. J. Volcanol. Geotherm. Res. 135 (4), 343-360, http://dx.doi.org/10.1016/j.jvolgeores.2004.03.009.

Fontaine, F., Rabinowicz, M., Boulegue, J., Jouniaux, L., 2002. Constraints on hydrothermal processes on basaltic edifices: inferences on the conditions leading to hydrovolcanic eruptions at Piton de la Fournaise, Réunion Island. Indian Ocean. Earth. Planet. Sci. Lett. 200, 1-14, http://dx.doi.org/10.1016/ S0012-821X(02)00599-X.

Fournier, C., 1989. Spontaneous potentials and resistivity surveys applied to hydrogeology in a volcanic area: case history of the Chaine des Puys (Puy-de-Dome, France). Geophys. Prospect. 37, 647-668, http://dx.doi.org/10. $1111 / \mathrm{j} .1365-2478.1989 . t b 02228 . x$.

Gabalda, G., Bonvalot, S., Hipkin, R., 2003. CG3TOOL: an interactive computer program to process Scintrex CG-3M gravity data for high resolution applications. Comput. Geosci. 29, 155-171, http://dx.doi.org/10.1016/S00983004(02)00114-0.

Genthon, P., Rabinowicz, M., Foucher, J.-P., Sibuet, J.-C., 1990. Hydrothermal circulation in an anisotropic sedimentary basin: application to the Okinawa Back Arc Basin. J. Geophys. Res., http://dx.doi.org/10.1029/JB095iB12p19175.

Gudmundsson, A., et al., 1992. The 1991 eruption of Hekla, Iceland. Bull. Volcanol. 54, 238-246, http://dx.doi.org/10.1007/BF00278391.

Guichet, X., Jouniaux, L., Pozzi, J.-P., 2003. Streaming potential of a sand column in partial saturation conditions. J. Geophys. Res. 108, 2141, http://dx.doi.org/10. 1029/2001JB001517.

Hase, H., Hashimoto, T., Sakanaka, S., Kanda, W., Tanaka, Y., 2005. Hydrothermal system beneath Aso volcano as inferred from self-potential mapping and resistivity structure. J. Volcanol. Geotherm. Res. 143, 259-277, http://dx.doi. org/10.1016/j.jvolgeores.2004.12.005.

Head, J., Wilson, L., 1989. Basaltic pyroclastic eruptions: influence of gas-release patterns and volume fluxes on fountain structure and the formation of cinder cones, spatter cones, rootless flows, lava ponds and lava flows. J. Volcanol. Geotherm. Res. 37, 261-271, http://dx.doi.org/10.1016/0377-0273(89)900838.

Heggy, E., Clifford, S., Grimm, R., Dinwiddie, C., Wyrick, D., Hill, B., 2006. Ground-Penetrating Radar sounding in mafic lava flows: assessing attenuation and scattering losses in Mars-analog volcanic terrains. J. Geophys. Res. 111, E06S04, http://dx.doi.org/10.1029/2005JE002589.

Ishido, T., 2004. Electrokinetic mechanism for the "W"-shaped self-potential profile on volcanoes. Geophys. Res. Lett. 31, L15616, http://dx.doi.org/10.1029/ 2004GL020409.

Ishido, T., Mizutani, H., 1981. Experimental and theoretical basis of electrokinetic phenomena in rock-water systems and its applications to geophysics. J. Geophys. Res. 86, 1763-1775, http://dx.doi.org/10.1029/JB086iB03p01763.

Ishido, T., Pritchett, J., 1999. Numerical simulation of electrokinetic potentials associated with subsurface fluid flow. J. Geophys. Res. 104, 15247-15259, http://dx.doi.org/10.1029/1999JB900093.

Jackson, D., Kauahikaua, J., 1987. Regional self-potential anomalies at Kilauea Volcano. Volcanism in Hawaii. U.S.G.S. Prof. Paper 1350, 947-959 (Chapter 40)

Jousset, P., Dwipa, S., Beauducel, S., Duquesnoy, F., Diament, M., 2000. Temporal gravity at Merapi during the 1993-1995 crisis: an insight into the dynamical behaviour of volcanoes. J. Volcanol. Geotherm. Res. 100, 289-320, http://dx. doi.org/10.1016/S0377-0273(00)00141-4.

Keller, G.V., Frischknecht, F.C., 1996. Electrical Methods in Geophysical Prospecting. Pergamon, London.

Labazuy, P., 1996. Recurrent landslide on the submarine flanks of Piton de la Fournaise volcano (Réunion Island). Volcano Instability on the Earth and other planets. In: Mc Guire, W., Jones, A.P., Neuberg, J. (Eds.), Geol. Soc. Lond, pp. 293-305, http://dx.doi.org/10.1144/GSL.SP.1996.110.01.23.

Lénat, J., Fitterman, D., Jackson, D., Labazuy, P., 2000. Geoelectrical structure of the central zone of Piton de la Fournaise volcano (Réunion). Bull. Volcanol. 62 , 75-89, http://dx.doi.org/10.1007/s004459900058.

Loke, M.H., Barker, R.D., 1996. Practical techniques for 3D resistivity surveys and data inversion. Geophys. Prospect. 44, 499173.

Lopez, T., Antoine, R., Baratoux, D., Rabinowicz, M., Kurita, K., dUston, L., 2012. Thermal anomalies on pit craters and sinuous rilles of Arsia Mons: possible signatures of atmospheric gas circulation in the volcano. J. Geophys. Res. 117, E09007, http://dx.doi.org/10.1029/2012JE004050.

Lu, N., Zhang, Y., Ross, B., 1999. Onset of gas convection in a moist porous layer with the top boundary open to the atmosphere. Int. Commun. Heat Mass Transfer 26 (1), 33-44, 1999.

Malengreau, B., Lénat, J., Bonneville, A., 1994. Cartographie et surveillance temporelle des anomalies de polarisation spontanées (PS) sur le Piton de la Fournaise. Bull. Soc. Géol. France 165 (3), 221-232.

Marsden, S., Tyran, C., 1986. The streaming potential generated by flow of wet steam in capillary tubes. In: Proceedings, Eleventh Workshop on Geothermal Reservoir Engineering, Stanford University, Stanford, California, SGP-TR-93.

Merle, O., Lénat, J.-F., 2003. Hybrid collapse mechanism at Piton de la Fournaise (Réunion Island. Indian Ocean J. Geophys. Res. 108, 2166-2176, http://dx.doi. org/10.1029/2002JB002014.

Michel, S., 1998. Effets électriques et magnétiques sur le Piton de la Fournaise (Ile de la Réunion): influence de la circulation des fluides (Ph.D. thesis). Université Paris VII.

Michel, S., Zlotnicki, J., 1998. Self-potential and magnetic surveys. Tools to investigate faulting, fluid circulation and eruptive dynamism of volcanoes: Example of La Fournaise (Réunion Island). J. Geophys. Res. 103 (8) 17845-17857, http://dx.doi.org/10.1029/98JB00607.

Michon, L., Saint-Ange, F., Bachèlery, P., Villeneuve, N., Staudacher, T., 2007. Role of the structural inheritance of the oceanic lithosphere in the magmato-tectonic evolution of the Piton de la Fournaise volcano (La Réunion Island). J. Geophys Res. 112, B04205, http://dx.doi.org/10.1029/2006JB004598.

Moore, J., Glaser, S., 2004. Laboratory observations of an advancing boiling front in a porous medium and correlation to self-potential measurements. In: Proceedings, 29th Stanford Workshop on Geothermal Reservoir Engineering.

Morgan, F., Williams, E., Madden, T., 1989. Streaming potential properties of Westerly granite with applications. J. Geophys. Res. 94, 12449-12461, http:// dx.doi.org/10.1029/JB094iB09p12449.

Ohsawa, S., Yusa, Y., Oue, K., Amita, K., 2000. Entrainment of atmospheric air into the volcanic system during the 1995 phreatic eruption of Kuju Volcano, Japan. J. Volcanol. Geotherm. Res. 96, 33-43.

Ormond, A., Boulègue, J., Genthon, P., 1995. A thermoconvective interpretation of heat flow data in the area of Ocean Drilling Program leg 116 in a distal part of the Bengal fan. J. Geophys. Res. 82, 8083-8095, http://dx.doi.org/10.1029/ 95JB00072.

Rabinowicz, M., Sempéré, J.-C., Genthon, P., 1998. Thermal convection in a vertical permeable slot: implications for hydrothermal circulation along mid-ocean ridges. J. Geophys. Res. 104 (B12), 29275-29292, http://dx.doi.org/10.1029/ 1999JB900259.

Rabinowicz, M., Rouzo, S., Sempéré, J.-C., Rosemberg, C., 1993. Three-dimensional mantle flow beneath mid-ocean ridges. J. Geophys. Res. 98 (B5), 7851-7869, http://dx.doi.org/10.1029/92JB02740.

Revil, A., Cerepi, A., 2004. Streaming potentials in two-phase flow conditions. Geophys. Res. Lett. 31 (11), L11605, http://dx.doi.org/10.1029/2004GL020140.

Revil, A., Schwaeger, H., Cathles, L., Manhardt, P., 1999. Streaming potential in porous media. 2. Theory and application to geothermal systems. J. Geophys. Res. 104, 20033-20048, http://dx.doi.org/10.1029/1999JB900090.

Ross, B., Amter, S., Lu, N., 1992. Numerical Studies of Rock-Gas Flow in Yucca Mountain. Sandia National Laboratories, SAND91-7034.

Sandmeier, K., 2004. ReflexW Version 3.5. Program for Processing of Seismic, Acoustic or Electromagnetic Reflection, Refraction, and Transmission Data. Software Manual. Karlsruhe, Germany., pp. 345. 
Sprunt Eve, S., Mercer Tony, B., Djabbarah Nizar, F., 1994. Streaming potential from multiphase flow. Geophysics 59 (5), 707-711, http://dx.doi.org/10.1190/1. 1443628.

Strahser, M., Jouniaux, L., Sailhac, P., Matthey, P.D., Zillmer, M., 2011. Dependence of seismoelectric amplitudes on water content. Geophys. J. Int. 187, 1378-1392.

Telford, W., Geldart, L., Sheriff, R., 1990. Applied Geophysics. Cambridge University Press, New York

Vieira, C., Meineult, A., Zamora, M., 2012. Laboratory study of self-potential signals during releasing of $\mathrm{CO}_{2}$ and $\mathrm{N}_{2}$ plumes. C.R. Geosci. 344, 498-507.

Weeks, E.P., 1987. Effect of topography on gas flow in unsaturated fractured rock-concepts and observations. In: Evans, D.D., Nicholson, T.J. (Eds.), Flow and Transport Through Unsaturated Fractured Rock, Geophysical Monograph 42. American Geophysical Union, Washington, pp. 165-170 (HQS.880517.3214).
Wohletz, K., Heiken, G., 1992. Volcanology and Geothermal Energy. Los Alamos Series in Basic and Applied Sciences. Univ. California Press, Berkeley, CA, pp. 432 (1992).

Zablocki, C., 1976. Mapping thermal anomalies on an active volcano by the self-potential method, Kilauea, Hawaii. In: Proceedings, 2nd U.N. Symposium of the Development and Use of Geothermal Resources, San Francisco, California, May 1975, pp. 1299-1309.

Zablocki, C., 1978. Streaming potentials resulting from the descent of meteoric water. A possible source mechanism for Kilauean self-potential anomalies. Geotherm. Resour. Council Trans. 2, 747-748.

Zodhy, A., Anderson, L., Muffler, L., 1973. Resistivity, self-potential and induced polarization surveys of a vapor-dominated geothermal system. Geophysics 38, 1130-1144 